\title{
Önceden Kaymış Aşırı Konsolide Killi Şevlerin Kesme Mukavemetinin Hızlı Kesme Yöntemi ile Araştırılması
}

\author{
Gültekin KIRIM*1(i), Alper CEBECí2 \\ ${ }^{1}$ Boğaziçi Üniversitesi, Mühendislik Fakültesi, İnşaat Mühendisliği Bölümü, 34342, İstanbul, Türkiye \\ 2 Ortadoğu Teknik Üniversitesi, Mühendislik Fakültesi, İnşaat Mühendisliği Bölümü, 006800, Ankara, Türkiye
}

(Alınış / Received: 13.10.2019, Kabul / Accepted: 26.03.2020, Online Yayınlanma / Published Online: 20.08.2020)

\section{Anahtar Kelimeler}

Önceden kaymıș șev, Yüksek ve alçak plastiliteli killi toprak,

Reziduel ve kesme kuvveti, Aşırı konsolide, Şev kararlılı̆̆l,

Hızlı kesme testi
Özet: Killi zeminler geoteknik biliminin başlangıcından beri incelenmekte olabilir, ancak kilin farklı yükleme durumlarında ve farklı şartlardaki davranışı halen incelenmektedir. Bu çalışma, yüksek ya da düşük plastitedeki killerden oluşmuş önceden kaymıș șevlerle ilgilidir. Kaymadan sonra, "zeminin gücü reziduel değere düşer" düşüncesi genel anlamda kabul görmüş ve önceden kaymış şevlerin kararlılık hesaplarında bu değer kullanılmıştır. Bu noktada, eğer şev kilden oluşuyorsa sorusu akıllara gelebilir; daha detaylı düşünürsek, eğer şev yüksek ya da düşük plastisiteli aşırı konsolide killerden oluşuyorsa kesme davranışında ne gibi farklılıklar olabilir? İşte bu çalışmanın ana noktası budur. Deneylerde, düşük plastisiteli örnekler için Kaolin, yüksek plastisiteli örnekler icin ise ağırlıç̧a \%50 Kaolin ve \%50 Bentonit karışımı kullanılmıştır. Deney aşamaları olarak, önce örnekler aşırı konsolide edilir, daha sonra reziduel değerlerine kadar kesme deneyi sürdürülür ve son olarak da hızlı kesme deneyi gerçekleștirilir. 30 (otuz) testin sonunda sonuçlar beklendiği gibi elde edilir. Yüksek plastik numuneler aynı normal stres altında daha düşük mukavemet değerleri vermektedir; asıl ilginç sonuç, reziduel mukavemet ile daha yüksek bir kesme hızındaki kesme mukavemeti arasındaki değerler arasındaki farktır.

\section{Investigation of Shear Strength of Prefailed Overconsolidated Clayey Slopes by Fast Shearing}

\section{Keywords}

Pre-failed slope,

High and low Plastic clayey soil,

Residual and shear strength, Overconsolidation,

Slope stability,

Fast shearing test

\begin{abstract}
Clayey soils might be investigated since the days of the beginning of the geotechnical science. The behaviour of the clays under different loading and environmental conditions is still under investigation. This study is dealing with the pre-failed soil slopes consist of high and low plastic overconsolidated clays. After failure of a slope, the thought of "soil strength reduces its residual strength" has found general acceptance and residual strength is applied to the calculations of the stability of pre-failed slopes. At this point, the question comes to the minds; if the slope formed with clayey soil or more specifically, high or low plastic overconsolidated clays, what would be the difference in shear behaviour after failure? That is the main point of this study. In the tests, Kaolin clay is used for low plastic samples and 50\% Kaolin $+50 \%$ Bentonite in weight are used for high plastic clay samples. As testing steps; first, samples are over-consolidated, then sheared until their residual strengths and finally tested after a certain time at the highest rate of shearing of the apparatus. At the end of the 30 (thirty) tests, the results are obtained as expected. High plastic samples could serve lower strength values under the same normal stress; however, the interesting result was about the difference in values between the residual strength and the shear strength at a higher rate of shearing.
\end{abstract}




\section{Introduction}

Earthquakes and their effects on environment are crucial issues that Turkey and many other countries must be prepared. Especially landslide prone areas require a special consideration. One of the most critical parameters for the design is the soil strength parameters. These parameters vary depending on the soil history.

Geotechnical literature reveals information about laboratory test methods to determine the dynamic properties and responses of clayey soils, residual strength, strength parameters of normally consolidated clays under seismic loading, and some experimental studies on progressive failure of a slope during earthquakes. The results of these studies have been of great importance for earthquakes science.

As a result of such research, it is known that at large strains, the shear strength falls below the peak value and the clay in a narrow zone adjacent to the failure plane will soften and reach the critical state. However, because of the non-uniform strain in the specimen the exact point on the curve corresponding to the critical state is uncertain. With continuing shear displacement, the shear strength continues to decrease, below the critical state value, and eventually reaches a residual value at a relatively large displacement.

If the clay contains a relatively high portion of plate-like particles, a reorientation of these particles parallel to the failure plane occurs as the strength decreases towards the residual value.

Several forces like earthquake forces produce shear stresses throughout the soil mass, and a movement will occur unless the shearing resistance on every possible failure surface throughout the mass is sufficiently larger than the shear strength. The solution for the failure model is highly sensitive to the shear strength. Moreover, the determination of appropriate shear strength is the most difficult part in the analysis.

Slopes in over-consolidated clays require special consideration. A number of cases are on record in which failures in this type of clay have occurred long after dissipation of excess pore water pressure had been completed. Analysis of those failures showed that the average shear strength at failure was below the peak value. It is probable that large strains occur locally due to the presence of fissures, resulting in the peak strength being reached, followed by a gradual decrease towards the critical state value. The development of large local strains can lead eventually to a progressive slope failure where one can observe a gradual reduction in strength to the residual value. When a local failure occurs, the strength reduces to residual with a load transfer to adjacent zones, which then fail, and result in a general potential slip surface. The study of progressive failure gives insight into the interdependence of the stability of adjacent elements or sections of a soil mass. Progressive failure does not require the entire mass to be simultaneously in a state of failure. A local point of failure may result in sufficient load transfer to an adjacent point that the soil is overstressed, resulting in a mass failure.

It is also possible that there could be a pre-existing slip surface in that type of clay and it is reactivated. In such cases, a considerable slip movement could have taken place previously, sufficiently large for the shear strength to fall below the critical state value and towards the residual value. Thus, for an initial failure in overconsolidated fissured clay the relevant strength for the analysis of long-term stability is the critical state value. However, for failure along a pre-existing surface the relevant strength shall be the residual value.

Our research direction is the effects of earthquakes on previously failed over-consolidated clayey soil slopes with high and low plasticity. The artificially pre-failed slopes would be expected to withstand earthquake loads with its residual strength value. In this research, tests have been conducted in order to investigate the behavior of pre-failed over-consolidated clayey slopes with high and low plasticity under fast impacts (i.e. earthquakes) simulated by fast shearing.

\section{Material Properties and Methodology}

Clay is used as a rock term and also as a particle-size term in the mechanical analysis of sedimentary rocks, soils, etc. As a rock term, it is difficult to define precisely, because of the wide variety of materials that have been called clays. In general, the term clay implies a natural, earthy, fine-grained material which develops plasticity when mixed with a limited amount of water. By plasticity is meant the property of the moistened material to be deformed under the application of pressure, with the deformed shape being retained when the deforming pressure is removed. Chemical analyses of clays show them to be essentially silica, alumina, and water, frequently with appreciable quantities of iron, alkalies, and alkaline earths.

As a particle-size term, the clay fraction is that size fraction composed of the smallest particles. The maximum size of the particles in the clay size grade is defined differently in different disciplines. In geology the tendency has been to follow the Wentworth 1922, scale and to define the clay grade as material finer than about 4 microns [1]. In soil investigations, the tendency is to use 2 microns as the upper limit of the clay size grade. Although there is no sharp universal boundary between the particle size of the clay minerals and nonclay minerals in argillaceous sediments, a large number of analyses have shown that there is a general tendency for the clay minerals to be concentrated in a size less than 2 microns, or that naturally occurring larger clay-mineral particles break down easily to the size when the clay is soaked in water. Also such analyses have shown that the nonclay minerals usually are not present in particles much smaller than 1 to 2 
microns. A separation at 2 microns is frequently about the optimum size for the best split of the clay mineral and nonclay-mineral components of natural materials. There is, therefore, a fundamental reason for placing the upper limit of the clay size grade at 2 microns.

Clays contain varying percentages of clay-grade material and therefore, varying relative amounts of nonclay-mineral and clay-mineral components. Many materials are called clays in which the clay grade and clay-mineral component make up considerably less than half the total rock. In such materials the nonclay is frequently not much coarser than the maximum for the clay grade, and the clay-mineral fraction may be particularly potent in causing plasticity. In general, fine-grade materials have been called clay so long as they had distinct plasticity and insufficient amounts of coarser material to warrant the appellations silt or sand. If particle size analyses are made, the term clay would be reserved for a material in which the clay grade dominates. However, names have been and are applied most frequently solely on the basis of the appearance and bulk properties (e.g., plasticity) of the sample.

\subsection{Factors controlling the properties of clay materials}

The factors which control the properties of clay materials or the attributes which must be known to characterize completely a clay material may be classified as follows:

\subsubsection{Clay-mineral Composition}

This refers to the identity and relative abundance of all the clay-mineral components. Since certain clay minerals which may be present in very small amounts may exert a tremendous influence on the attributes of a clay material, it is not adequate to determine only the major clay-mineral components. Thus, a small amount $(5 \% \pm)$ of montmorillonite in a clay is likely to provide a material very different from another clay with the same composition in all ways except for the absence of montmorillonite. In order to make complete claymineral determinations, it is frequently necessary to fractionate the clay grade to concentrate minor constituents so that adequate analytical data can be obtained. Fortunately, such a concentration can often be attained because the various clay minerals frequently occur in particles of different sizes or break down easily in water to particles of different size. Also, the clay minerals must be determined in their natural state. For example, care must be taken that the analysis will reveal the natural hydration state of the mineral and their ion exchange composition.

\subsubsection{Nonclay-mineral composition}

This refers to the identity of the nonclay minerals, their relative abundance, and the particle-size distribution of the individual species. Calcite, dolomite, large flakes of mica, pyrite, feldspar, gibbsite, and other minerals are very abundant in some clay materials. The nonclay minerals in clay materials tend generally to be concentrated in particles coarser than about 2 microns. There are, however, materials in which they are much finer grained. Many clay materials contain fine iron oxide or hydroxide, which acts as a pigment.

\subsubsection{Organic material}

This refers to the kind and amount of organic material contained in clay material. In general, the organic material occurs in clay materials in two ways: it may be present as discrete particles of wood, leaf matter, spores, etc., or it may be present as organic molecules adsorbed on the surface of the clay-mineral particles. The discrete particles may be present in any size from large chunks easily visible to the naked eye to particles of colloidal size which act as a pigment in the claymineral material.

The total amount of organic material can be determined simply by readily available standard analytical procedures. Values may be obtained from the difference between total loss on ignition and determination of loss of water, sulfur, and other inorganic volatiles. Such volatiles are not precise but are usually adequate. Differential thermal analyses provide a crude determination of amount of organic material gives a dark gray or black color and organic content. A very small amount of organic material may have a very large pigmenting effect.

\subsubsection{Exchangeable ions and soluble salts}

Some clay materials contain water-soluble salts which may have been entrained in the clay at the time of accumulation or may have developed subsequently as a consequence of weathering or alteration processes, as in the oxidation of pyrite to produce sulfates. It is frequently necessary to wash out the soluble salts before other attributes of the material are studied. Some salts may act to flocculate the clay, so that it cannot be dispersed for particle-size analysis or for fractionation preliminary to clay-mineral analysis until the salts are washed out. Common water-soluble salts found in clay materials are chlorides, sulfates, and carbonates of alkalies, alkaline earths, aluminum, and iron.

The clay minerals and some of the organic material found in clay materials have significant ion-exchange capacity. The ion-exchange capacity of the clay minerals and the organic components, as well as the identity and relative abundance of the exchangeable ions which are present, are extremely important attributes of clay materials.

\subsubsection{Texture}

The textural factor refers to the particle-size distribution of the constituent particles, the shape of 
the particles, the orientation of the particles in space and with respect to each other and the forces tending to bind the particles together. Some knowledge of the particle-size distribution of the coarser grains can be obtained quickly by microscopic examinations, and detailed determinations can be made by sieving and/or wet sedimentation methods. Fine-grained particles require wet methods, and this applies to the claymineral fraction.

\subsection{Overconsolidated clays}

Many soils have been subject to high stresses at some stage in their depositional history. Such stresses cause the porosity of the soil to decrease. Later, these high stresses may be alleviated or entirely removed through the erosion of overlying later sediments.

This process is termed overconsolidation, and is an early stage in the lithification of sediment. The terms 'soil' and 'rock' are used here in quite a different manner from that in which they are used in the pure geological sciences. For an engineer, geological materials are soil until they become so hard that they must be excavated with special tools, wedges, picks, pneumatic and hydraulic drills, or blasted with explosives. The overconsolidated clays, silty clays and clay-shales, therefore count as soils, not rocks, in this classification. Yet, they are clearly different from the soft sediments of recent age. This kind of soils would be classified as normally consolidated if they had never experienced higher stresses than those to which they are presently subjected.

One major difference between the normally consolidated and overconsolidated soils, apart from consistency, or undrained strength, is the presence of fissures in overconsolidated soils. Terzaghi has suggested that clays may be divided into two categories, fissured clays and intact clays. Very stiff clays invariably contain fissures that are filled with small joints or cracks. These stiff clays have such high shearing strength that questions seldom arise regarding to adequacy of their strength to prevent failure. The real problems in such clays occur when water enters the cracks. They have been opened slightly by additional stresses imposed by a change of loading, and this leads to slaking and formation of a soft clay matrix within the joint system. Intact clays may be defined as clays which are free of joints and fissures [2]. The occurrence of fissures, which are after all only one category in a wide variety of different discontinuity surfaces in the soil mass, is related to the stress relief element of overconsolidation process. Their genesis is by no means understood, but is no doubt due in some way to differential strains during the initial consolidation, and the later swelling as stress is removed. Fissures have a bearing on the shear strength of the soil.

A second major difference is the presence of higher lateral stresses in the ground, which are left 'locked in' as vertical stresses are released. These then give greater stress relief effects if excavations are opened up in the ground.

In addition, the overconsolidated soils inevitably have lower porosities than their normally consolidated counterparts. This leads to their having a stiffer behavior in respect of deformations under applied load, and more dilatant behavior under shear because of the denser packing of the particles.

Overconsolidation is normally caused by the removal of later sediments but can be caused in other ways, which are over consolidation by the weight of overlying ice and desiccation. Salt-marsh deposits, and river alluvium on the flood plain, can be overconsolidated by the strong suction of normal evaporation, and these may be supplemented by influence of plant roots. Rapidly accreting sediments may then have several lightly or even strongly overconsolidated horizons in an otherwise normally consolidated profile.

\subsection{Slope stability}

Slopes are either a natural consequence of geological and geomorphological evolution or the result of mankind's perceived need to modify the landscape by direct or indirect means. Careful consideration of the stability and instability of natural or manmade slopes is central to good engineering practice. There is a large body of knowledge concerning the various parameters, variables and models that are important to a clear understanding of the processes affecting the stability of slopes [3].

Landslides or soil slope failures are among the most common natural hazards. As with most natural hazards, they are often characterized by the catastrophic examples. Unlike most natural hazards, however, most damage is not caused by extreme events, but by uncounted (and often unreported) minor events.

The hazards associated with landslides are as diverse as the types of failure. Falls may damage roads, buildings at the base of a steep slope, injure climbers, or remain on a road as a hazard to drivers. Slumps usually damage utilities within or below the slide mass, but seldom cause a threat to life. Translational slides can be the most catastrophic of all. In addition to presenting a local hazard to structures and utilities, they can cause damage and death both far from and only slightly below the source. Flows, in addition to the above hazards, can flow around well-built structures, preserving them but causing damage from water and mud.

The reasons of slope failures could be grouped into three headings; geological, morphological and human causes. 
- Geological causes

a. Weak or sensitive materials

b. Weathered materials

c. Sheared, jointed, or fissured materials

d. Adversely oriented discontinuity (bedding, schistosity, fault, unconformity, contact, and so forth)

e. Contrast in permeability and/or stiffness of materials

- Morphological causes

a. Tectonic or volcanic uplift

b. Glacial rebound

c. Fluvial, wave, or glacial erosion of slope toe or lateral margins

d. Subterranean erosion (solution, piping)

e. Deposition loading slope or its crest

f. Vegetation removal (by free drought)

g. Thawing

h. Freeze-and-thaw weathering

i. Shrink-and-swell weathering

- Human causes

a. Excavation of slope or its toe

b. Loading of slope or its crest

c. Drawdown (of reservoirs)

d. Deforestation

e. Irrigation

f. Mining

g. Artificial vibration

h. Water leakage from utilities

Although there are multiple types of causes of landslides, the three that cause most of the damaging landslides around the world are these:

- Landslides and Water

- Landslides and Seismic Activity

- Landslides and Volcanic Activity

\subsection{Slopes and overconsolidation}

The softening of clay results in up to $80 \%$ loss of strength in some deposits after 30 to 70 years, and is probably responsible for the extreme variation of material strength observed at several landslide sites. In order to be able to account for such changes and variations in the engineering behaviour of clays, it is important to understand the mechanisms by which the material properties of clays are altered. There is very little understanding of the factors that control the amount and rate of softening in clay deposits.

Two primary mechanisms have been proposed as playing important roles in the softening of clay. These include the equilibration of negative pore pressures and the deterioration of fissures by means of chemical alteration or slaking. As discussed below, these two mechanisms are not entirely independent of one another, and it is probable that both act to some degree in all clay deposits. In addition, these mechanisms surely act in conjunction with the progressive failure mechanism in such a way that they are enhanced by progressive failure. It may be difficult to uncouple the effects of one mechanism from the other.

Still, it is essential that is recognized which material and environmental factors control the extent and rate of softening at any given site. In addition, the engineer needs to know the effect that a given amount of deterioration will have on the strength and stress strain behaviour of the clay deposit.

There are three important effects of fissuration in controlling the behaviour of clay deposits. First, they provide inherent planes of weakness along which shear can occur. It is for this reason that clays must also be considered from a rock mechanics point of view. Second, the fissures greatly increase the permeability of clay deposits. Without the conduits provided by fissures, most clay would be virtually impervious. Third, fissures significantly increase the surface area exposed to weathering agents.

Thus, in addition to significantly weakening a clay mass, fissures greatly enhance the process of deterioration in clays, by allowing a greater influx of water and other weathering agents into the interior of the mass. The rate and extent of softening is highly dependent on the presence of fissures.

In addition, whether softening occurs in response to the equilibrium of negative pore pressures, or by chemical alteration or slaking, softening surely weakens fissure wall material first before progressing further into the clay mass.

As unloading occurs in response to excavation or natural erosion, negative pressures can be created within the pore fluid of a clayey deposit. If the permeability of the clayey material is low, these negative pore pressures may persist for extended periods of time, and may act to initially strengthen the deposit. However, as these negative pore pressures are equilibrated by the influx of fluid, the apparent strength resulting from the tensile pressures is destroyed.

Based on piezometric measurements within the blue and brown zones of the London clay proposed that long-term reduction in the strength of the London clay might be related to extremely slow dissipation of negative pore pressures, which had been generated in response to the cutting of the slope [4]. Previous measurements in the London clay had indicated that the value of Bishop's average pore pressure ratio, ru, as defined in Figure 1, was in the range between 0.25 and 0.35 for conditions of equilibrium. This value had been reached in slope of brown London clay that had been cut 125 years previously. However, in the facing slope that had been recut 19 years before the piezometric measurements were taken the pore pressures were only one-half of the equilibrium value. Skempton thus concluded that the equilibration of negative pore pressures in the London clay required about 40 to 50 
years, and could thus account for the loss of strength in slopes of London clay.

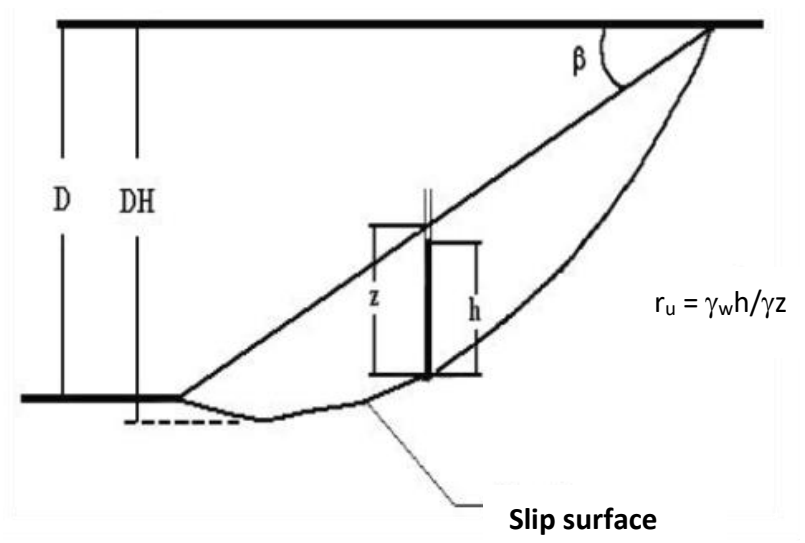

Figure 1. Definition of Bishop's average pore pressure ratio, $\mathrm{r}_{\mathrm{u}}[4]$.

$\mathrm{h}=$ piezometric height

$\gamma_{\mathrm{w}}=$ unit weight of water

$\gamma=$ unit weight of clay

$r_{u}=$ average value of $r_{u}$ around slip surface

$\mathrm{D}=$ depth factor

As been determined previously by several researchers, Skempton confirmed that the strength mobilized at failure was equal to the "fully-softened" strength. The very slow equilibrium of negative pore pressure was therefore, not proposed as a mechanism by which peak, strength was exceeded or by-passed. The proposed mechanism does; however, suggest that the delays in slope failures of the London clay might be controlled by the time required dissipating negative pore pressures, rather than the time necessary for deterioration to occur. It is important to note that the slides evaluated by Skempton in his 1964 report, deliberately excluded shallow slips and slips in zones of seasonal variation [4]. Unlike the slides evaluated, these slips typically occur after exceptionally heavy rainfall, especially following prolonged dry periods. For these cases, as well as for the slides investigated by Skempton, the mechanism of softening must still be assessed.

That negative pore pressures still exist in the London clay 20 to 40 years after excavations are both surprising and significant. It had been assumed that the presence of fissures would allow rapid dissipation of negative pore pressures. However, it is not necessary to implicate extremely low permeability to account for the presence of negative pore pressures many years after excavation.

It is important to assess whether the negative pore pressures result entirely from the initial slope cutting, or whether they might in addition result from soil suction associated with material deterioration and swelling. Furthermore, it should be determined whether failure of the London clay occurs primarily along fissures. If this is the case, one must be concerned about measuring the equilibrium of pore pressure along fissures, and not the equilibrium within the clay mass itself. Finally, equilibration of negative pore pressure is certainly associated with the influx of more water into the material. It is important to consider how the generation and dissipation of the pressures might occur in conjunction with the deterioration and swelling.

As early as 1844, an engineer, Gregory and a geologist, Sir Henry Delabache observed the softening of fissures within the London clay and suggested that progressive softening might account for slips that occurred several years after construction [5]. Soon after, it was suggested that clay slopes along canals would eventually be reduced to inclinations similar to those exhibited in the natural terrain. These observations were not expounded on further until Skempton stated that one of the reasons for the long delay in the development of soil mechanics could be found in the apparently 'treacherous' and unpredictable behaviour of stiff-fissured clays: especially since they are widespread in south east England and in France [6].

Terzaghi reintroduced the idea that the strength of the stiff, fissured clays, such as the London clay, depended on the spacing of the fissures and on the degree of softening adjacent to the fissures. He also emphasized the behavioural difference between the relatively stable non-fissured clays and the troublesome, fissured clays [7]. Terzaghi and Peck described the process by the following; "almost every stiff clay is weakened by a network of hair cracks or slickensides. If the surfaces of weakness subdivide the clay into small fragments 1 in. or less in size, a slope may become unstable during construction or shortly thereafter. If the spacing of the joints in the clay is greater than several inches, slopes may remain stable for many years or even decades after the cut is made. The lapse of time between the excavation of the cut and the failure of the slope indicates a gradual loss of the strength of the soil. Before excavation, the clay is very rigid, and the fissures are completely closed. The reduction of stress during excavation causes an expansion of the clay, and some of the fissures open. Water then enters and softens the clay adjoining these fissures. Unequal swelling produces new fissures until the larger chunks disintegrate, and the mass is transformed into a soft matrix containing hard cores. The water seems to cause only deterioration of the clay structure; seepage pressures appear to be of no consequence [8].

Since Terzaghi's statements, numerous researchers have observed softening and increased water content of the London clay along failure zones and within unfailed fissures. It is of course important in future studies to distinguish between softening that occurs prior to failure and that occurring as a result of failure. Further evidence for the deterioration of fissures prior to slope failure, comes from Hutchinson who noted that mudflows in the London clay often consisted of a mud matrix surrounding hard clay fragments [9]. 
Many slides have been occurred within the upper partially weathered layers of the lays of North America and Italy. In addition, numerous authors have reported localized softening occurring along failure planes and irregularly into fissures in lower zones. Scully discussed in detail the very localized existence of "seeps" consisting of highly weathered Pierre with water contents greater than $130 \%$. Even at depths of over $30.5 \mathrm{~m}$, softened zones were found such that the undrained compressive strength varied from the softened strength of $320 \mathrm{kPa}$ to $9.1 \mathrm{MPa}$ within a 0.61 m distance. Certainly, the occurrence of these softened zones must be joint controlled.

Deterioration of the strength along fissures can result from either (1) chemical alteration, or from (2) increasing the amount of water adsorbed by the clay material. Chemical alteration of a clay deposit can involve either the precipitation or deposition of new minerals, or the chemical transformation of existing minerals. Furthermore, chemical alteration can act to either decrease strength by breaking bonds, by increasing porosity, or it can actually increase strength by creating new bonds, particularly in the presence of cementing agents. The mineralogy can be altered such that properties such as the swelling potential, or the residual strength, are either more favourable, or less favourable to stability of the slope or foundation.

Although the effects of chemical alteration are probably of extreme importance in controlling the long-term strength of clay deposits, this dissertation will not discuss this process or its effects in any detail. Unfortunately, extensive investigations regarding chemical alteration and its potentially important effects in clays are surprisingly few.

In the natural environment, clays are typically jointed. The highest strength mobilized by clays in the field is never greater than the strength of jointed or slickensided samples. In addition, much evidence has been presented which indicates that the softening of clay deposits is initiated along fissures, thereby further concentrating the zones of weakness along fissure planes. Therefore, it is generally important to consider the jointed nature of clays, and not threat these materials strictly as classical soils.

Since the first suggestions by Gregory and Delabeche that the strength of the London clay was being reduced by a softening of the clay material adjacent to fissures, several other researchers have alluded to this possible mechanism to account for the deterioration of strength in many clays [5].

Stark and Eid presented a study about "Slope Stability Analysis in Stiff Fissured Clays" [10]. Results of torsional ring shear direct shear, and triaxial compression tests on cohesive soils reveal that the fully softened shear strength is stress-dependent and related to the type of clay mineral and quantity of claysize particles. An empirical relationship for the fully softened friction angle is presented that is a function of liquid limit, clay-size fraction, and effective normal stress. Studies of first-time slides, i.e., slopes that have not undergone previous sliding, in stiff fissured clay with a liquid limit between 41 and 130\%, suggest that the mobilized shear strength along the failure surface can be lower than the fully softened shear strength. Recommendations are presented for estimating the mobilised shear strength in first-time slides based on soil plasticity. Soils with a liquid limit greater than $30 \%$ exhibit a large difference between the fully softened and residual friction angles. In these soils, the presence or absence of a pre-existing shear surface should be clarified. The following conclusions are based on results of torsional ring shear, direct shear, and triaxial compression tests on clays, mudstones, and shales and studies of first-time slides in stiff fissured clays.

The mobilized shear strength along the failure surface in first-time slides through stiff fissured clay with a liquid limit between 50 and 130\% can be lower than the fully softened shear strength. A study of 14 firsttime slides through stiff fissured clay suggests that the mobilized shear strength can be as low as the average between the fully softened and residual shear strengths. Additional case histories should be located and the effect of other geological factors, such as fissure spacing and bedding existence, should be studied to verify this conclusion.

The peak shear strength of the soil mass should be used to locate the critical slip surface in slopes that have not undergone previous sliding. In high-plasticity stiff fissured clays (liquid limit $>50 \%$ ), the fully softened shear strength is approximately equal to the peak shear strength of the soil mass and can be used to locate the critical failure surface. The nonlinearity of the fully softened failure envelope should be incorporated into this analysis. In slopes that have undergone previous sliding, the critical slip surface is usually well defined, and thus does not need to be located.

The numerical difference between the fully softened and the residual friction angles is a function of clay mineralogy and effective normal stress. Natural soils with a liquid limit greater than $30 \%$ exhibit the largest difference in these friction angles (up to 160). In these soils, the presence or absence of a preexisting shear surface should be clarified during the subsurface investigation.

\subsection{Pre-failed slopes}

Slopes of clay and weak mudstone often contain shear surfaces at residual strength, which were created by previous landslides or tectonic movements. Different soils in distinct conditions have also different response to failure and strength reduction after failure.

When designing a cutting in clay it is at the outset necessary to investigate whether instability could be caused by reactivating failure along pre-existing shear 
surfaces. If that is the case, the residual strength should be used. Where no pre-existing shear surfaces are present, the design must guard against a 'first-time' slide. In first-time slides, two limiting conditions can be recognized. The first is the 'short-term' or 'end of construction' case, in which no overall water content changes occur and the pore-pressures are controlled by changes in stress consequent upon making the excavation. They are difficult to predict with accuracy. At present, the relevant effective stress shear strength parameters are not known with certainty. For shortterm design the $\varphi \mathrm{u}=0$ analysis is therefore used, in saturated clays, making proper allowance for the effects of discontinuities such as joints and fissures, anisotropy, and rate of testing. The second is the 'longterm' case, corresponding to steady seepage porepressures. Here, the analysis is carried out in terms of effective stress. There is abundant evidence that in over-consolidated fissured clays the cohesion intercept c' operating at the time of failure is far less than the value measured in conventional laboratory tests on small specimens. Indeed, it appears that the relevant field value of c' in such clays is almost zero [11].

The need for strain softening to occur as the soil weakens from peak strength to critical state makes it very likely that localization of deformation in thin rupture zones will occur. This will tend to obscure overall observation of attainment of critical states. The critical state represents in many ways a lower bound to the strength of soils, but a lower, residual strength may be seen if it is possible for orientation of particles parallel to a failure plane to develop. It is, however, very important to distinguish between the drop of strength which arises because of particle reorientation and the drop of strength which occurs in overconsolidated soils as they suck in water and soften on shearing. That softening emerges naturally in an elastic-plastic model of soil behavior. Once a localized plane or thin zone of failure has developed, then such continuum models of soil behavior lose their attraction; subsequent response must be described in terms of stresses on and displacements across that thin zone.

Loose sand, normally consolidated clay and lightly overconsolidated clay $(\mathrm{OCR}<4)$ show a gradual increase in shear strength as the shear strain increases, until an approximately constant shear stress called Critical Shear Stress $\tau$ cs. The soil becomes compressed with shearing, i.e. it becomes denser, and hence the void ratio reduces until a constant value called critical void ratio ess is reached (Figure 2).

In dense sand and heavily overconsolidated clay $(\mathrm{OCR}>4)$, shearing causes a rapid increase in shear stress until a peak value is reached. A drop in shear stress then follows with continuing increase in shear strain. This feature is referred to as strain softening and is attributed to the appearance of localized failure zones called shear bands that have a thickness of no more than 15 grains. The soil within the shear band undergoes intense shearing, while the rest of the soil masses behave as rigid bodies. When a shear band develops in some types of overconsolidated clays, the particles become oriented parallel to the direction of the shear band, causing the final shear stress of these clays to decrease below the critical state shear stress. This behavior is represented as in Figure 3.

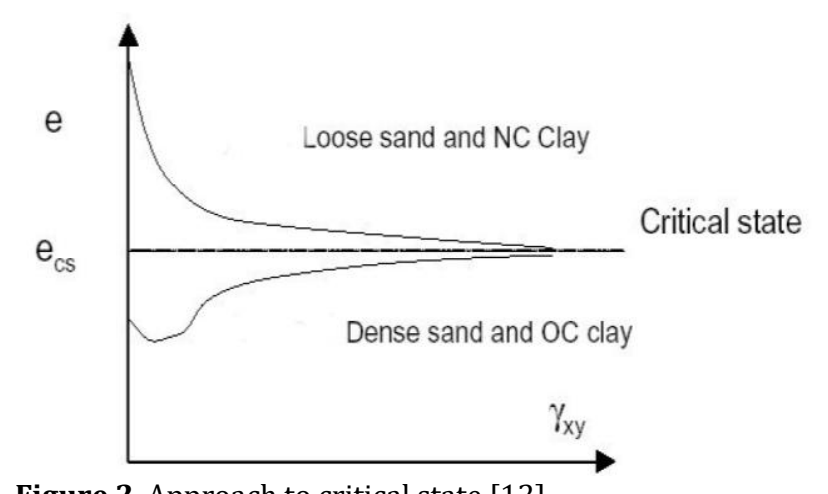

Figure 2. Approach to critical state [12].

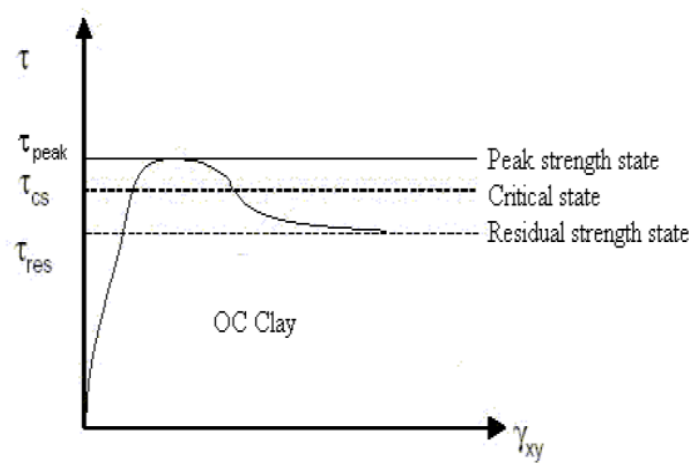

Figure 3. Behavior of overconsolidated clay [12].

Residual strength is the lowest strength of a soil in the residual state, where flat particles have become aligned with the slip plane and the flow is laminar. Residual strength state occurs after a large amount of strain has taken place. For evaluating the stability of such slopes during earthquakes, dynamic properties of materials with preexisting shear surfaces at or close to residual strength should be known e.g. as developed along natural landslip surfaces. This type of soil compresses initially due to particle adjustments and then expands (i.e. it becomes looser), until a critical void ratio ecs is reached. (The critical state in soil mechanics is defined as the state at which no further volume change occurs under continuing shearing).

Kuwano et al. (1991) observed in the experiments, which were conducted on cohesive soils from landslide sites that the peak strength of the presheared sample increased with the increase in the displacement rate [13]. However, the residual strength did not show a clear tendency with the shear rate. In the dynamic loading tests, the sample with high plasticity index showed ductile stress versus residual displacement relationship (Figure 4).

The dynamic strength of presheared sample was higher than the static strength of presheared sample, i. e. the 
static residual strength (Figure 5). The ratio of two strengths increased as the plasticity index increased (Figure 6). The ratio of the dynamic strength to the static strength was about 1.3 to 2.0. The value was almost the same whether the specimen was unsheared or presheared.

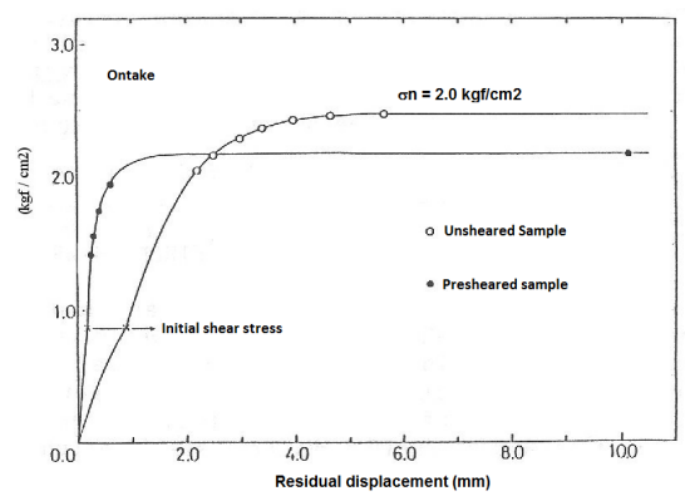

Figure 4. Stress versus residual displacement [13].

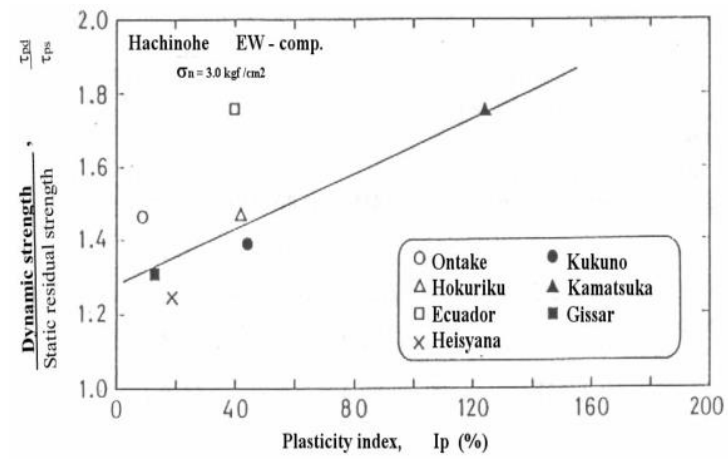

Figure 5. Static and dynamic strength of on take silt [13].

where,

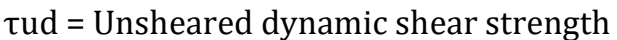
$\tau p d=$ Presheared dynamic shear strength

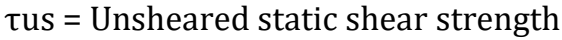
$\tau$ ps $=$ Presheared static shear strength

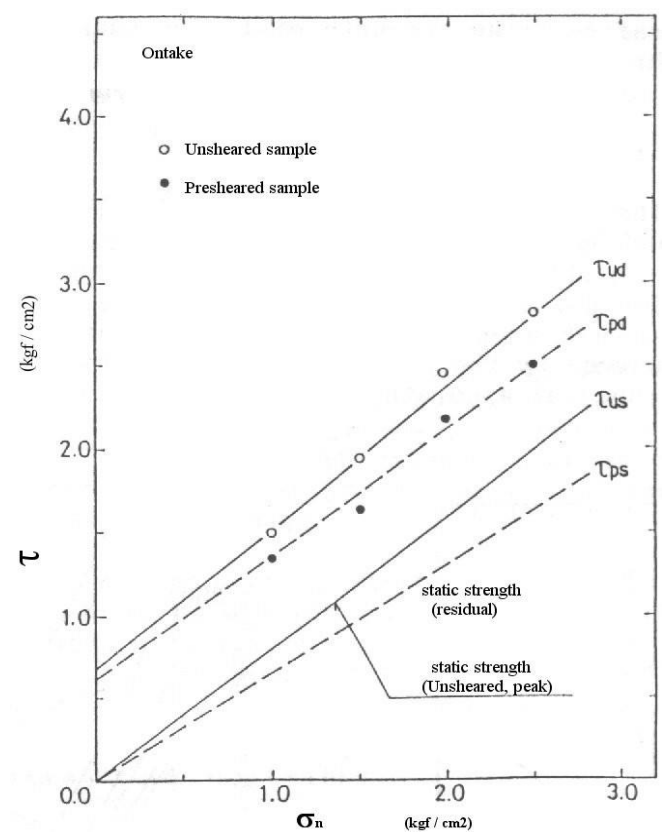

Figure 6. Strength increase due to dynamic loading versus plasticity index [13].

\subsection{Earthquake effects simulation with fast shearing of pre-existing shear zones}

Pre-existing shear zones at or close to residual strength are frequently present in soil due to previous movement caused by landsliding or tectonic forces. The influence of fast shearing on the strength of such zones must be considered in the study of stability of soil masses sliding on pre-existing shears under various disturbing events, such as the alteration of external loading of sliding mass, seasonal groundwater changes, and dynamic events such as earthquakes and blasts.

The residual strength of soil, measured at slow drained rates of shearing, has been studied extensively in laboratories over the past 30 years. Various correlations between the slow residual strength and index properties have been proposed in the literature. Lupini, Skinner and Vaughan found that the residual strength, measured at slow drained rates of shearing, resulted from three modes of shearing [14]. These reflect the quantity of plate-like particles present in the soil.

A turbulent mode (TU) is in soils with a high proportion of rotund particles, or possibly in soils dominated by plate-like particles when the coefficient of interparticle friction between these particles is high. Shearing involves rotation of the rotund particles and a particle orientation has a negligible effect. The residual friction angle is high and depends primarily on the shape and the packing of rotund particles and not on the coefficient of inter-particle friction. A shear zone, once formed, is a zone of different porosity only and it is considerably modified by subsequent stress history.

A sliding mode $(\mathrm{S})$ is in soils with a high proportion of plate-like particles, low friction particles. These particles orientate in the direction of shearing and deform predominantly by sliding on a thin polished continuous shear surface. The residual friction angle is high and depends primarily on mineralogy, pore water chemistry and the coefficient of inter-particle friction. A shear zone, once formed, is a permanent feature of the soil and is not significantly affected by subsequent stress history.

A transitional mode (TR) is in soils with no dominant particle shape. Shearing involves both turbulent and sliding behavior in different parts of a shear zone in which orientated shear surfaces can partly be formed but are continuously disrupted by the rotund particles. In this mode, the residual friction angle is sensitive to small changes in grading of the soil.

Most of the early investigations on the residual strength of soil were concerned with the measurement of the residual strength of cohesive soils at relatively slow rates of displacement. They found that the residual strength of cohesive soils is not significantly rate-dependent. The existence of a significant rate effect on the residual strength of cohesive soils was 
first identified in the work of Lupini and Martins $[14,15]$. Further research has been carried out since then to investigate and assess these rate effects [16].

Lemos, Skempton and Vaughan showed that if a shear zone is formed at residual strength by slow drained shearing and then tested at a fast rate, the following features are typically observed $[17,18]$ :

(a) There is initial threshold strength on the shear surface, mobilized at a negligibly small displacement. The threshold strength is a function of the rate of displacement and is considerably in excess of the slow drained residual strength.

(b) There is often a further increase in strength on the shear surface with fast displacement up to a maximum value, the fast peak strength, which is again a function of the rate of displacement.

(c) If, after fast shearing of a soil that shows transitional and sliding shear mode, the shear surface is tested slowly, an initial slow peak strength greater than the slow drained residual strength is measured, indicating that fast shearing causes disordering of the shear surface.

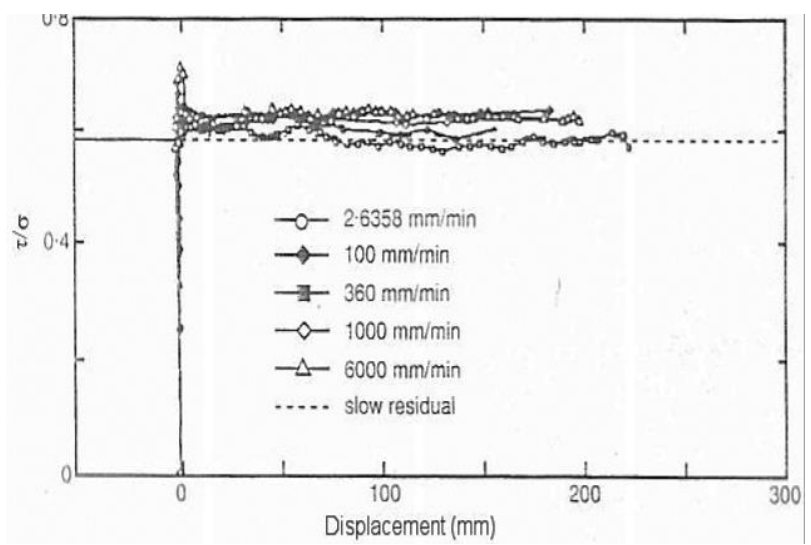

Figure 7. Fast stages of ring shear test that shows neutral rate effect [19].

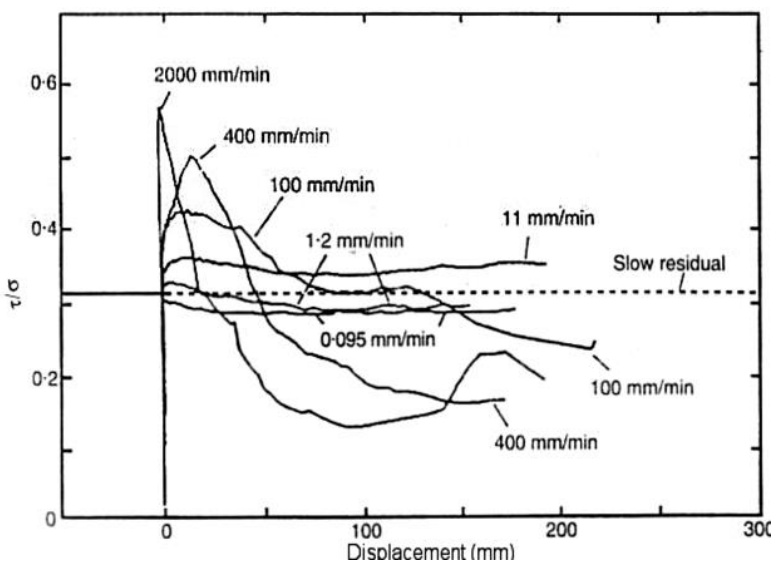

Figure 8. Fast stages of ring shear test that shows negative rate effect [19].

In the light of the study conducted by Tika et al. (1996), it is obvious that the fast shearing of the pre-existing shear zones of the soil generally have a tendency of higher shear strength values than the slow shearings, but also some other tendencies are observable (Figures 7 - 9) [19]. The soil history may be another effective point in shear strength. The overconsolidation is related with the soil history and the study did not include its effects on shear strength of the pre-sheared soils.

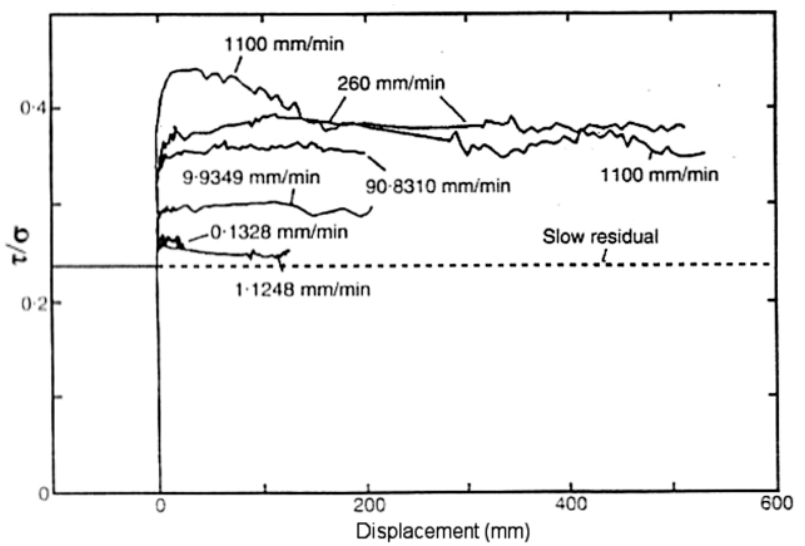

Figure 9. Fast stages of ring shear test that shows positive rate effect [19].

\subsection{Shear strength concept}

In the majority of troublesome stability problems, the soils involved are cohesive materials. Therefore, it may be stated that the importance of an understanding of the fundamentals of shearing strength will apply in greatest degree to cohesive soils. There probably is no phase of soil mechanics which has greater need of logical treatment and of freedom from blind use of ruleof-thumb methods. In fact, no physical property of cohesive soil is more complex than the shearing strength. This property depends on many factors, and the individual factors are themselves complicated but, in addition, they are interrelated to such a degree that it is extremely difficult to understand their combined action [2].

Generally, in the pseudo-static methods of analysis, the shear strength parameters used are those measured in conventional shear strength tests. This assumption appears to be justified by the relatively few examples where problems have arisen.

However, in cases where seismic loading may cause movement along an existing discontinuity (such as a fault or old slip surface), significant decreases in the value of $\varphi$ ', have been reported by Skempton.

In the Fourth Rankine Lecture the following points were made relating to long-term slope stability in overconsolidated clays [4]:

(a) After a slide has taken place the strength on the slip surface is equal to the residual value. The residual strength is associated with strong reorientation of the clay particles and is represented by an angle of shearing resistance $\varphi^{\prime}$ at peak strength (Figure 10). 
(b) First-time slides in slopes in non-fissured clays correspond to the strengths only slightly less than the peak.

(c) First-time slides in fissured clays correspond to strengths well below the peak.

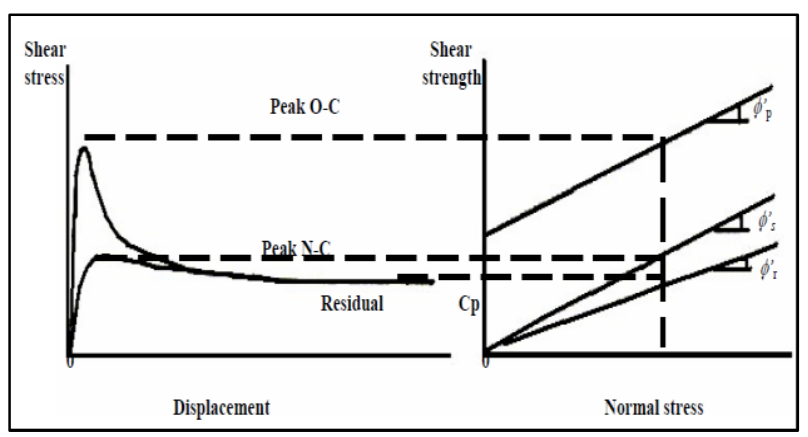

Figure 10. Shear characteristics of clays [20].

(d) Some form of progressive failure must be operative to take the clay past the peak. This could be simply the result of a non-uniform ratio of stress to strength along the potential slip surface; but probably the fissures play an important role as stress concentrators and in leading to softening of the clay mass.

(e) Granted a progressive failure mechanism, the limiting strength would be residual, and it is therefore reasonable to express the actual strength at the time of failure as a function of the upper (peak) and lower (residual) limits, i.e. by the residual factor.

(f) In natural slopes of London Clay, the strength has fallen approximately to the residual value.

(g) The residual strength obtains on pre-existing shear surfaces, whether these are the result of tectonic shearing or old landslides.

All these points except $5^{\text {th }}$ are still believed to be valid. In $5^{\text {th }}$ point the argument short-circuits the critical state, and it fails to take into account the comparatively small magnitude of the displacements which typically precede a first-time slide in overconsolidated clays [21].

\subsubsection{Peak and residual shear strengths}

When a soil is subjected to shear, an increasing resistance is built up. For any given applied effective pressure, there is a limit to the resistance that the soil can offer, which is known as the peak shear strength $\tau p$. Frequently the test is stopped immediately after the peak strength has been clearly defined. The value $\tau p$ has been referred to, in the past, as simply the shear strength of the clay, under the given effective pressure and under drained conditions.

If the shearing is continued beyond the point where the maximum value of the shear strength has been mobilized, it is found that the resistance of the clay decreases, until ultimately a steady value is reached. This constant minimum value is known as the residual strength $\tau \mathrm{r}$ of the soil. The soil maintains this steady value even when subjected to very large displacements.

The residual shear strength condition is of considerable practical importance since, if the soil in situ already contains slip planes or shear surfaces, then the strength operable on these surfaces will be less than the peak strength, and if sufficient displacement has taken place, the strength may be as low as the residual strength.

There are a number of circumstances, as a result of which shearing of the soil may already have taken place, and the principal processes, summarized by Morgenstern et al., are [21]:

- landsliding,

- tectonic folding,

- valley rebound,

- glacial shove,

- periglacial phenomena and

- non-uniform swelling.

The identification of the existence of shear surfaces is a problem of great importance during any site investigation, particularly where mass movements are involved. It is generally accepted that the residual shear strength of a soil is independent of stress history effects, not influenced by specimen size and ratedependent to only a small extent unless very rapid rates of shearing are used. The major difficulty in determining the residual shear strength lies in the fact that large displacements may be necessary to achieve the required degree of orientation of the particles.

The most satisfactory methods for measuring residual shear strength in the laboratory, in many ways, are to obtain undisturbed samples that contain a natural slip surface and then test them in the shear box apparatus so that failure occurs by sliding along the existing slip plane. Alternatively, an artificial slip plane can be produced by cutting the specimen with a thin wire-saw. Much of the early work on determining the residual shear strength of soils in the laboratory was performed using multi-reversal type tests in the shear box on previously un-sheared material.

The results of tests to measure residual shear strength in the shear box and triaxial apparatus have been reported by Skempton [4]. There are practical difficulties with each of these tests, and they also have the major disadvantage that none of them permits the complete shear-stress-displacement relationship to be obtained.

In all clays the residual strength will be reached after a continuous principal shear surface has developed and, in the field this state appears to be attained typically after mass movements of the order of several feet. 
Methods for measuring residual shear strength are as following:

- Shear box :

a. Tests on natural shear surfaces

b. Reversal-type tests

c. Cut-plane tests

- Triaxial :
a. Tests on natural shear surfaces
b. Cut-plane tests

- $\quad$ Ring shear: The large displacements required to define the complete shear-stress displacement relationship can be obtained by using the ring-shear (or torsional shear) apparatus. The apparatus, shown diagrammatically, consists of two pairs of metal rings, which hold an annular sample. The sample is subjected to a normal stress and then one pair of rings (normally the lower pair) is subjected to rotation. It is therefore a form of direct shear test, and failure occurs along a predetermined plane, as with the shear box. This type of apparatus was probably first used by Hvorslev and Tiedemann [22,23].

- Effect of shearing speed on residual strength of clay: In general, the activated landslides show a displacement rate from $5 \mathrm{~cm} /$ year to 50 $\mathrm{cm} /$ day. A strength parameter mobilized on a slip surface changes, accompanying a change of displacement rate in an objective landslide block. Therefore, this factor should be taken into account while carrying out a slope stability analysis with a great accuracy.

The residual strength of a soil is one of the most important strength parameters to evaluate the stability of a reactivated landslide slope [4]. The relationship between the residual strength and the shear displacement rate of various soils has been examined using reversal box shear test apparatus [24-26] or ring shear test apparatus $[18,27,28]$. Skempton emphasized that the change in residual strength can be neglected when the shear displacement rate is between 0.002$0.01 \mathrm{~mm} / \mathrm{min}$ generally adopted in the laboratory tests [26]. Yatabe et al. reported that the residual strengths of clays in fractured-zone landslide areas hardly increase with increasing the shear displacement rate [27]. In contrast, Lemos et al. pointed out that the residual strength of soils with a high clay content increases with the increasing shear displacement rate, whereas the residual strength of soils with a low clay content decreases with the increasing shear displacement rate [18]. Suzuki et al. have clarified that the residual strength of a clay increases linearly with an increase in the logarithm of shear displacement rate under the fully drained conditions [28].

To clarify the effect of shear displacement rate on the residual strength of soil, consolidated constant pressure ring shear tests with different shear displacement rates $(0.02-2.0 \mathrm{~mm} / \mathrm{min})$ were performed. Based on the test results, the variation of the residual strength with the shear displacement rate is discussed from the viewpoints of the clay fraction, the plasticity index, and the activity with respect to a new parameter, $\alpha$ ', proposed.

According to the results of the tests, Suzuki et al. pointed out that the residual strength of a soil is notably changed by the shear displacement rate, and this tendency seems to be dependent on the physical properties of the soil [28]. Figures 11a and 11b show the relationships between the shear-normal stress ratio, $\tau / \sigma \mathrm{N}$ and the shear displacement, $\theta$ for kaolin and mudstone, respectively. For example, $\theta=10 \mathrm{rad}$ is equivalent to $\mathrm{D}=400 \mathrm{~mm}$. The shear-normal stress ratio of all specimens clearly shows a strain-softening characteristic. Also, $\tau$ / $\sigma \mathrm{N}-\theta$ curves are influenced by the rate of shear displacement angle. The residual strength of a soil is generally defined as a constant minimum shear stress during a drained shear test. However, it is difficult to exactly judge whether the relationship between the shear stress (or the shearnormal stress ratio) and the shear displacement obtained by the ring shear test becomes a constant value after a large shear displacement. So, a hyperbolic curve is applied to approximate the post-peak relation between the shear-normal stress ratio and the shear displacement angle, and the shear-normal stress ratio at the residual state is defined as an asymptotic value of the hyperbola. The applicability of this method was sufficiently supported by the test results of kaolin and natural clays under various test conditions.
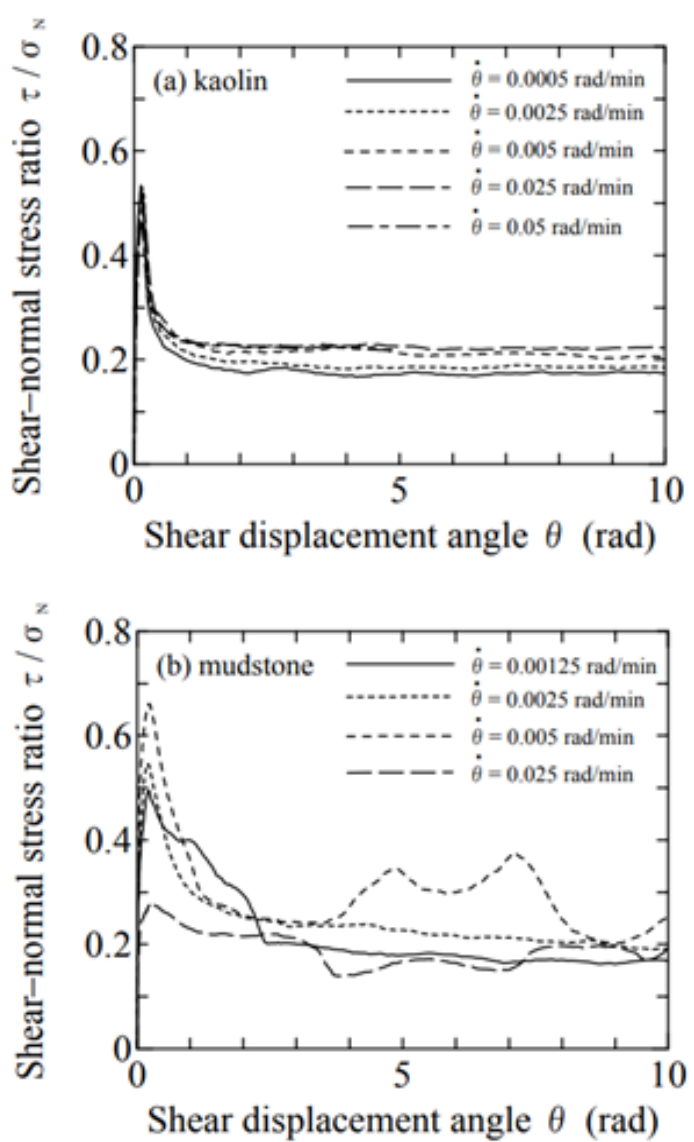

Figure 11. Relationship between shear-normal stress ratio and shear displacement angle for (a) kaolin and (b) mudstone. 
Relationships of shear displacement rate to peak strength and residual strength:

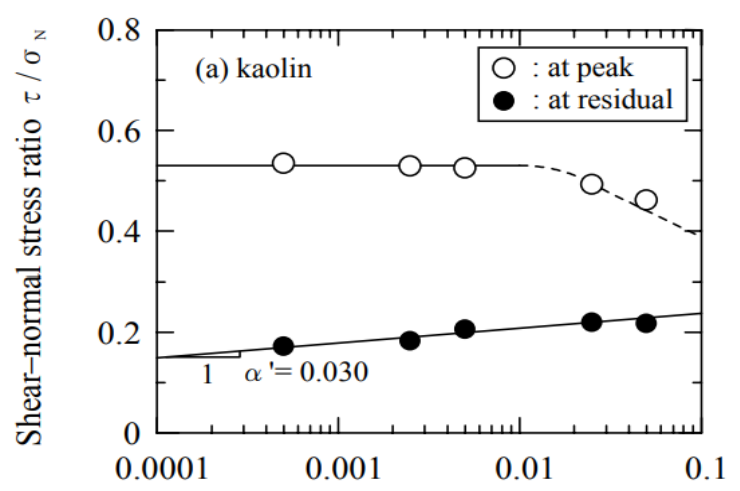

Rate of shear displacement angle $\dot{\theta}$ ( $\mathrm{rad} / \mathrm{min})$

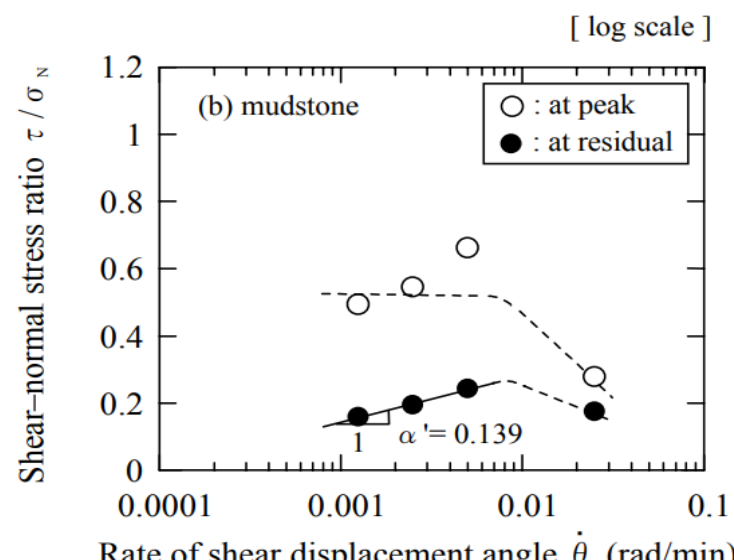

[ log scale ]

Figure 12. Relationship between shear-normal stress ratio and shear displacement angle rate for (a) kaolin and (b) mudstone.

Figures 12(a) and 12(b) show the relationships between the shear-normal stress ratios at peak and residual states, i.e. $\tau p / \sigma \mathrm{N}, \tau \mathrm{r} / \sigma \mathrm{N}$ and the shear displacement angle rate, $\theta$ for kaolin and mudstone, respectively. In the case of kaolin, $\tau p / \sigma N$ decreases with increasing the shear displacement angle rate above $\theta=0.025 \mathrm{rad} / \mathrm{min}(\mathrm{D}=1.0 \mathrm{~mm} / \mathrm{min}$ ), whereas $\tau \mathrm{p}$ / $\sigma \mathrm{N}$ becomes constant in a range of 0.0005 to 0.025 $\mathrm{rad} / \mathrm{min}$. In the case of mudstone, $\tau \mathrm{p} / \sigma \mathrm{N}$ decreases with increasing the shear displacement angle rate above $\theta=0.005 \mathrm{rad} / \mathrm{min}(\mathrm{D}=0.2 \mathrm{~mm} / \mathrm{min})$. These results agree with the previous results [28]. These phenomena may be induced by the generation of excess pore water pressure near the shear surface. In contrast, $\tau \mathrm{r} / \sigma \mathrm{N}$ for kaolin and mudstone increases linearly with an increase in the logarithm of the shear displacement angle rate below $\theta=0.025$ and 0.005 $\mathrm{rad} / \mathrm{min}$, respectively. $\tau \mathrm{p} / \sigma \mathrm{N}$ becomes almost constant in the same range of shear displacement angle rate. It should be allowed to achieve a fully drained condition, so that the excess pore water pressure generated inside the specimen does not cause a substantial change in effective normal stress on the shear surface. To quantitatively evaluate these experimental data, a rate effect coefficient, denoted as $\alpha^{\prime}$, is proposed in the following equation: $\alpha^{\prime}=d(\tau r / \sigma N) / d(\log \theta)$, which gives $\alpha^{\prime}=0.030$ and 0.139 for kaolin and mudstone, respectively.

From this study, conclusions may be summed up as;

(a) The residual strengths of kaolin and mudstone were significantly influenced by the shear displacement rate

(b) The proposed parameter, a' is an important index for evaluating the effects of the shear displacement rate on the residual strength.

(c) There exist linear relationships between a' and the clay fraction and the plasticity index. Variation in the residual strength with the shear displacement rate seems to be relevant to the type and content of the clay minerals.

\section{Test}

In geotechnical engineering, laboratory simulations have been utilized to simulate geotechnical problems such as the interaction between substructure and soil or the interaction within water flow, soil, and external static or dynamic loads.

Stress history parameters like pre-consolidation pressure, OCR and material parameters, clay fraction, the size of specimens, and the rate of shearing, are very important, influencing the effective shear strength of a clay mass.

In this section, the methods involved in the preparation of the laboratory specimens for both direct shear and consolidation tests are discussed.

\subsection{Test material}

For the laboratory experiments, for low plastic clay Kaolinite and for high plastic clay 50\% Kaolinite $+50 \%$ Bentonite mixture in weight were used.

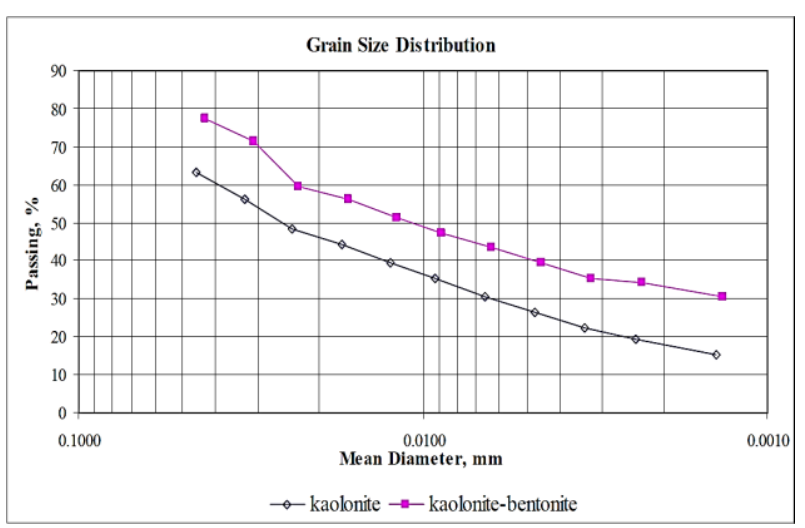

Figure 13. Grain size distribution of kaolinite and kaolinite + bentonite mixture.

To determine the characteristics of the soil, according to standard classification of soils for engineering purposes, USCS, (ASTM D 2487 - 00), Moisture Content Test (ASTM D 2216), Particle-Size Analysis (ASTM D 421, 422), Hydrometer (ASTM E100 - 95), Atterberg 
Limit Tests (ASTM 4318) tests were conducted. To reach average values for plastic limit, liquid limit and organic content, more than one set of experiments were performed.

The collected Kilyos soil was classified by the basic soil classification tests. Grain size distribution is given in Figure 13. The results of the classification tests are summarized in Table 1 . The table shows the average values of Liquid Limit, Plastic Limit, and Organic Content.

Table 1. Results of laboratory tests conducted on kaolinite and kaolinite + bentonite mixture

\begin{tabular}{lcc}
\hline Geotechnical Property & Kaolinite & $\begin{array}{c}50 \% \text { Kaolinite + } \\
50 \% \text { Bentonite }\end{array}$ \\
\hline Pass No. 200 sieve, per & 100 & 100 \\
cent & 27 & 60 \\
Liquid Limit, per cent & 19 & 23 \\
Plastic Limit, per cent & 8 & 37 \\
Specific Gravity (Gs) & 0.29 & 0.86 \\
Activity & $\mathrm{CL}$ & $\mathrm{CH}$ \\
Classification, (ASTM & & \\
\hline
\end{tabular}

\subsection{Test progress}

The behavior of the previously failed, overconsolidated clayey soils under earthquake like fast loading can be determined by a series of experiments. Specimens' plasticity and their characteristics should be known first. For that purpose, standard classification tests were employed, which are, Hydrometer test, and Atterberg Limits analyses. Specimens were initially consolidated to create an over-consolidation history on the samples. To determine the shear strengths of the prepared specimens, direct shear tests were conducted.

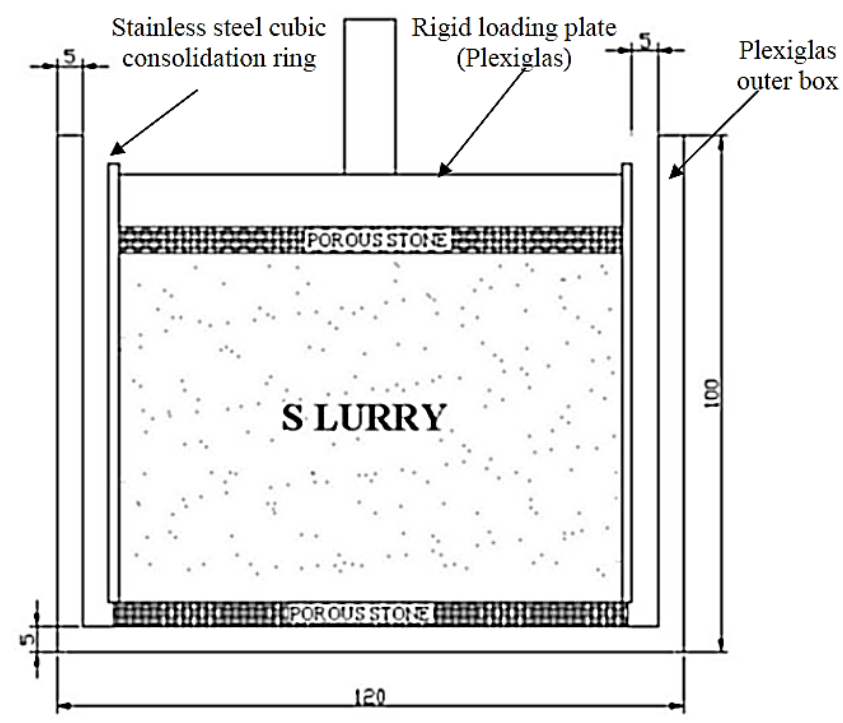

Figure 14. Cross-section of consolidation cell.

In preparation of the slurry that was used for consolidation, clays mixed with water equal to their liquid limit. After consolidation of the slurry, samples were put into $100 \mathrm{~mm}$ x $100 \mathrm{~mm}$ standard shear test cells. In order to obtain consolidated samples, EL250402 series oedometer and for the direct shear tests, EL26-2112 series Digital Direct/Residual Shear Apparatus were utilized. However, especially for this research, a set of new consolidation cells were developed. The rings were not standard circular rings. They were $100 \mathrm{~mm}$ x $100 \mathrm{~mm}$ square stainless-steel profile with a Plexiglass rigid loading plate above, and it was assembled in a Plexiglas outer shell to hold drained water (Figure 14).

Specimen preparation for consolidation:

First, clays were selected for the purpose of the study; for low plastic samples Kaolinite, for high plastic samples 50\% Kaolinite $+50 \%$ Bentonit by weight were employed.

To determine plasticity values of the samples Atterberg Limits analyses were conducted. Obtained plasticity values were in the desired limits for low and high plastic clays.

During the preparation of the samples, provision of special test rings suitable for this study becomes important. First, a $100 \mathrm{~mm}$ x $100 \mathrm{~mm}$ square shear cell was selected. The largest standard consolidation cell is circular with the diameter of $7.5 \mathrm{~cm}$, which was too small to trim samples for the shear cells chosen for this work. In order to work with numerous and undisturbed samples simultaneously, special consolidation cells would be required. That choice was driven by the need to carry out several tests at the same time. The ring produced used to obtain overconsolidated samples. The rings were $80 \mathrm{~mm}$ tall and obtained by cutting $100 \mathrm{~mm}$ by $100 \mathrm{~mm}$ square stainless steel box profile.

For the consolidation of the slurry a model EL25-0402 oedometer from ELE International was employed. The liquid limits of Kaolinite and the mixture are $27 \%$ and $60 \%$ respectively. For the slurry preparation, the amount of water content equal to the liquid limits was chosen. Water clay mixture was held for half an hour before pouring it into the square consolidation ring. During that time, water and clay formed a homogeneous structure by hand blending.

Before the slurry (with water content equals to liquid limit) was poured into the consolidation cell, a layer of filtration paper was placed on the porous stone to keep it from clogging. Then the slurry was poured in. The slurry was then covered, first with a two-layered filtration paper, and finally with a rigid loading plate. The weight of the loading plate was ignored because it was Plexiglas, which is very light in weight.

Over-consolidation:

The "over-consolidation ratio" (OCR) is defined as the highest stress experienced divided by the current stress.

At the beginning gradually, and then, with an increasing rate, loads were applied for the consolidation progress. The duration between each weight increment was minimally eight hours. The 
procedure was initiated with a $0.5 \mathrm{~kg}$ load and reached $37.6 \mathrm{~kg}\left(4.08 \mathrm{kgf} / \mathrm{cm}^{2}, \sim 400 \mathrm{kPa}\right)$, which was the chosen pre-consolidation pressure for this research. The whole procedure lasted two days.

For consolidation, the apparatus consisted of the following:

(a) Consolidometer consisted of a rigid base, a consolidation ring, porous stones, a rigid loading plate, and a support for a dial indicator. The various metal parts of the consolidometer were noncorrosive material.

(b) Consolidation ring completely and rigidly confined and supported the specimen laterally. The inner dimensions of the square ring were $100 \mathrm{~mm} \times 100 \mathrm{~mm}$ x $80 \mathrm{~mm}$. According to ASTM D 2435, the minimum specimen diameter is $50 \mathrm{~mm}$ and the minimum specimen height is $12 \mathrm{~mm}$ or shall not be less then ten times the maximum particle size and minimum specimen diameter-to-height ratio shall be 2.5; therefore, the prepared square consolidation ring dimensions satisfied the ASTM standards. The consolidation ring was made of a material that is noncorrosive (here stainless steel) in relation to the soil tested. The inner surface was highly polished.

(c) Porous stones under the specimen of soil were used to permit effective drainage. For routine testing, stones of medium porosity were satisfactory. The dimensions of the porous stones prevented any squeezing out of soil through the clearance spaces between the ring and stone. It permitted free compression of the specimen without binding. To minimize the possibility of binding, the sides of the upper porous stone of the fixed-ring consolidometer were slightly tapered away from the specimen, while both porous stones of the floating-ring consolidometer were tapered. The porous stones were cleaned after every test by boiling and flushing.

(d) Loading device was the beam-and-weight mechanism. The loading device was capable of transmitting axial load to the specimen quickly and gently. Also, the equipment was capable of maintaining a constant load for at least $24 \mathrm{hr}$. The equipment was calibrated to ensure that the loads indicated were those actually applied to the soil specimen.

(e) Dial Indicator reading counterclockwise, with a range of $20 \mathrm{~mm}$ and graduated to $0.010 \mathrm{~mm}$ was used.

(f) Other items used are:
a. Balances, sensitive to $0.1 \mathrm{~g}$.
b. Timing device, a watch or clock with second hand.
c. Distilled or dematerialized water.
d. Filter papers and a piece of sponge.

Direct shear tests and reaching residual strength: Upon the consolidation procedure was completed, the square samples were taken out of the consolidation cells, wrapped with plastic film, and placed into glass desiccators for resting. The desiccators contained water at the bottom to maintain humidity. The samples and the water, of course, were kept separate. Similar to the humidity room, those desiccators helped to preserve the original water content of the samples for the shear tests. The wrapped samples were carefully removed from the desiccators and trimmed for 100 $\mathrm{mm} \times 100 \mathrm{~mm}$ shear ring with the height $\sim 50 \mathrm{~mm}$. Trimmed samples were also stored in the desiccators until their turns came.

After trimming, each specimen in turn, was placed into the shear ring. Similar to the consolidation apparatus, for the shear test apparatus, a couple of porous stones and filtration papers were used. Samples in the shear test apparatus were kept in the distilled water under the pre-consolidation pressure that was $400 \mathrm{kPa}$. Under that loading $t_{50}$ values for each kind of the samples were determined by the help of the ADU. Then the samples were kept under corresponding normal load until its vertical displacement became stable. Here again, weights and pressure calculations were done according to desired normal stress values appropriate for the $100 \mathrm{~mm}$ x $100 \mathrm{~mm}$ specimens. The shear box can be seen in Figure 15.

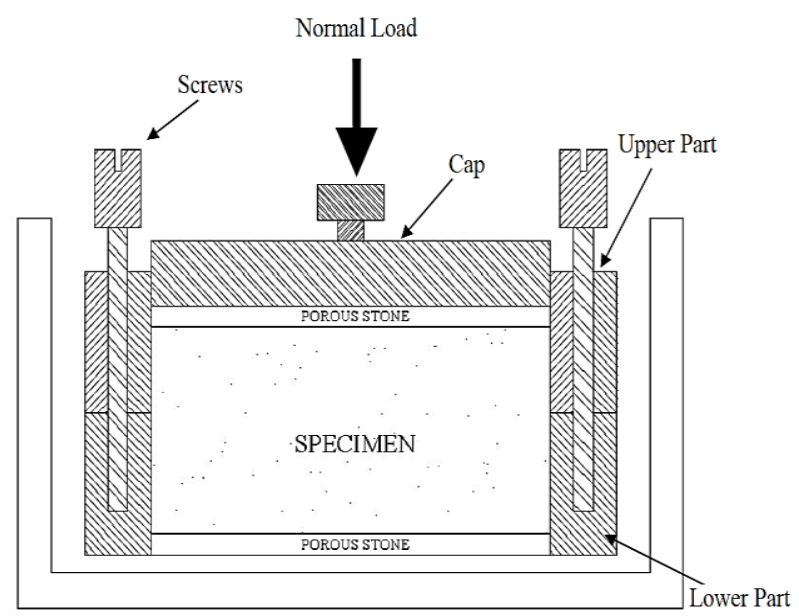

Figure 15. Shear test box with dimensions $100 \mathrm{~mm} \times 100$ $\mathrm{mm}$.

The apparatus consisted of the following:

- Shear box of stainless steel was open at the top and divided horizontally into two frames that fitted together accurately with alignment pins and elevating screws. The lower frame of the shear box contained a reservoir for water, with the bottom grooved or provided with a grooved area to permit drainage. The upper frame of the shear box contained an accurately machined piston, the bottom of which was also grooved to permit drainage. The upper frame provided horizontal locking screws to lock it to the piston within the upper frame of the box. The various metal parts of the shear box were also noncorrosive material.

A digital Direct/Residual Shear Apparatus, EL26-2112 from ELE International was used for the research. According to ASTM D 3080, the minimum specimen width for a square specimen should be $50 \mathrm{~mm}$ or not 
less than ten times the maximum particle size diameter, the minimum initial specimen thickness should be $12 \mathrm{~mm}$, but not less than six times the maximum particle diameter, and minimum specimen width to thickness ratio should be $2: 1$. Therefore, according to the standards, a specimen with the thickness of about $50 \mathrm{~mm}$ for $100 \mathrm{~mm}$ by $100 \mathrm{~mm}$ square shear box was adequate.

(a) Porous stones were porous metal plates. It was very important that the permeability of porous stones were not reduced by the collection of soil particles in the pores of the stones; hence, frequent checking and cleaning were required to ensure the necessary permeability by flushing and boiling.

(b) Loading devices were employed for applying the normal load and horizontal shear force to the specimen. The type of loading device used, met the following requirements:

a. The equipment for applying the normal load shall be capable of transmitting the load to the specimen quickly, without impact, and maintaining the load constant for the duration of the test. The equipment should be calibrated to ensure that the loads indicated are those actually applied to the soil specimen.

b. The horizontal shear force may be applied by either controlled-stress or controlled-strain methods, though the controlled-strain method is preferred in that the ultimate, as well as the maximum, stress can be determined. Controlled-strain equipment should be capable of shearing the specimen at a uniform rate of strain and should permit adjustment of the rate of strain over a relatively wide range. The controlled straining of the specimen is usually done with a motor and gear box arrangement, and the shear force is determined by a load-indicating device such as a proving ring or frame.

(c) Dial indicators for measuring (1) vertical deformation of the specimen, had a range of $1 \mathrm{~cm}$. and an accuracy of $0.01 \mathrm{~mm}$; and (2) horizontal displacement of the specimen, had a range of $2 \mathrm{~cm}$ and an accuracy of $0.01 \mathrm{~mm}$.

(d) Other items used were:

a. Balances, sensitive to 0.1 and $0.01 \mathrm{~g}$.

b. Timing device, a watch or clock with second hand.

c. Distilled or dematerialized water.

d. Equipment for preparing specimen (EM 1102-1906).

After the requirements for the direct shear test were satisfied, the direct shear tests were conducted to model the over-consolidated previously sheared (or failed) clayey soil slopes and also they were used to simulate earthquake loading by fast shearing with the same sample after a certain time. In the tests, a relatively thin, square specimen of soil was placed in the rigid box of EL26-2112 Series Digital Direct/Residual Shear Apparatus that has fully variable speed between 0.00001 to $10 \mathrm{~mm} / \mathrm{min}$. Its speed range is appropriate to simulate earthquake effect by fast shearing and it also provided acceptable slow strains to determine slow strain-rated residual shear strengths of the specimens. Minimum of three specimens, each under a different normal stress, were required to establish the relation between shear strength and normal stress, therefore, five specimens for each of the three loading conditions. Thus, peak and residual effective cohesion and internal friction angle values for each sample with duration times of, at least, 21 days were found. The magnitudes of the vertical pressures were $50 \mathrm{kPa}, 75 \mathrm{kPa}$ and $100 \mathrm{kPa}$. Because of the difficulties involved in controlling drainage of the soil specimen during the direct shear tests, the drained test method was employed.

Before starting the shear te st, according to desired OCR values, required loads were applied to the specimen in the $100 \mathrm{~mm} \times 100 \mathrm{~mm}$ shear ring. It was kept in water for swelling while it was still in the shear rings. Then, loaded specimen was prepared for the test with the desired OCR value and then ADU was set up to start the test. The experiment consisted of three steps; determining the shear strength, then residual strength and after, at least, 21 days, fast shearing response of the specimen. For the first two steps, for Kaolinite 0.1 $\mathrm{mm} / \mathrm{min}$ and for Kaolinite + Bentonit mixture 0.0667 $\mathrm{mm} / \mathrm{min}$ strain rates were employed.

All tests were done five times for three different normal loading to obtain the shear strength - normal stress relationship. Applied loads ( $5 \mathrm{~kg}, 7.5 \mathrm{~kg}$, and $10 \mathrm{~kg}$ ) were chosen according to desired normal stress values that were $\sim 50 \mathrm{kPa}, \sim 75 \mathrm{kPa}$, and $\sim 100 \mathrm{kPa}$. Shear stresses were measured with a three $\mathrm{kN}$ capacity load ring.

The dynamic (fast) shear strength tests, in the same manner, were conducted at least 21 days after the residual shear strength tests, with the strain rate of 10 $\mathrm{mm} / \mathrm{min}$ which was the maximum strain rate of the shear test apparatus EL26 - 2112.

A total 30 clay specimens and approximately $30 \mathrm{~kg}$ of clay were used for 210 shear tests. For all shear stress measurements, a three $\mathrm{kN}$ capacity load ring was utilized. For horizontal deformation measurement a dial gage of maximum $20 \mathrm{~mm}$ deformation length and for vertical deformation measurement another gage with maximum $10 \mathrm{~mm}$ deformation capacity were employed. Parallel to those gages, an ADU was connected with three analog inputs to measure horizontal, vertical strains and shear stress.

In the constant rate shear tests made by Kuwano et al. (1991), shear stress versus shear displacement relationships for the soil procured from the slope failure site in Ecuador are shown in Figure 16 [14]. The 
solid lines denote the results of pre-sheared samples, whereas, the broken line indicates the test results of unsheared sample. As shown in the Figure 16, the peak strength of the pre-sheared sample was higher for the higher shearing rate. On the other hand, the residual strength did not show a clear variation with the displacement rate. Though the residual strength was almost constant at displacement rates less than 1.0 $\mathrm{mm} / \mathrm{min}$, it increased or decreased with the shear rate depending on circumstances.

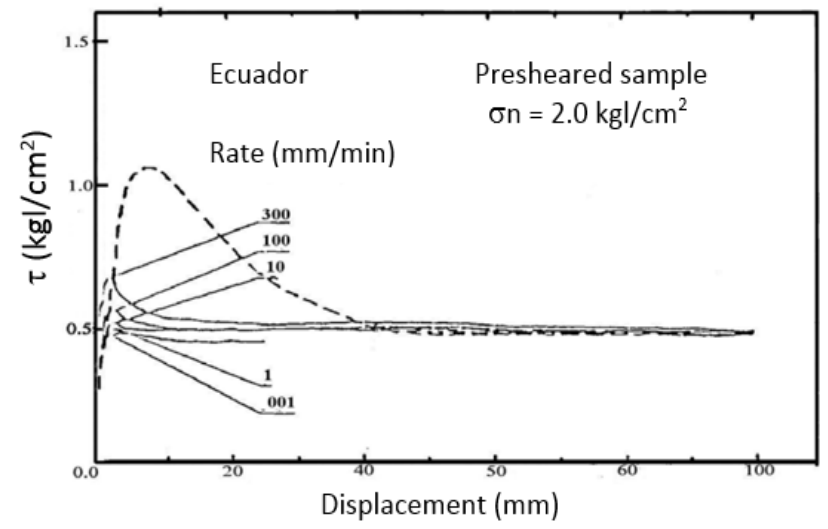

Figure 16. Shear stress versus shear displacement of constant rate shear tests [13].

Before shearing, specimens were rested in distilled water to swell under the appropriate load related to the normal stress value. During the tests, specimens were kept in distilled water for two reasons; first, because the tests were drained shear strength tests and second to prevent it from drying. Since the duration of the test was around ten hours, the specimen could lose water when squeezed.

To accomplish the over-consolidation, each sample was kept under desired loading according to its normal stress value until the vertical displacement ended. Before loading the sample, it was assured that the sample totally submerged in the distilled water and water level kept constant during the whole test time. For each sample, at least three forward shear tests were conducted one after another with the corresponding shear rates.

Due to the capability of the measurement devices, only forward movement data was collected. In other words, four forward and four backward shear tests were conducted but only the forward data could be collected. For each forward and backward movement of the shear box, at least $12 \mathrm{~mm}$ displacement was achieved, which is equal to 12 percent strain. Thus, after forward and backward shearing a minimum of $72 \mathrm{~mm}$ displacement was recorded.

Throughout the tests, data was recorded by the ADU at every 120 seconds for horizontal and vertical displacements and horizontal shear stress. Then, the automatic readings were collected and the most reasonable graphics for the shear tests were obtained. After three sets of shearing, water was discharged from the shear box, then the upper and lower shear rings were detached carefully before removing the samples. Wet samples were wrapped with stretch film and labeled with shearing direction, sample type and number, normal stress value and the date of the test.

Each sample was stored in special glass desiccators that contained water in its base to keep it humid. Samples, after shear tests, were stored in those desiccators for the fast shear tests. When the samples were placed into the desiccators, special care was taken not to disturb them and to prevent them from touching each other.

After 21 days, the pre-sheared samples were taken from the desiccators and again placed into the shear rings keeping in mind the shearing direction. Then, the samples were loaded with the related normal stress value and sheared with a $10 \mathrm{~mm} / \mathrm{min}$ strain rate, which is the maximum rate of the shear test apparatus. This time there was no water in the shear box, because it was an undrained fast shearing test.

All samples were kept in desiccators during the resting periods. Thus, the normal load did not exist while the samples were resting. This resulted in the swelling of the clayey samples and of the widening of fissures. In another words, the samples lost strength. Thus, at the time the samples were removed from the desiccators and placed into the direct shear device, they were at their weakest state. Then, the normal load was once again applied to the samples. Just after that, without waiting, the fast shear tests were initiated. Even under these circumstances, the samples demonstrated much stronger resistance to fast shearing in comparison to their residual strength. For this reason, keeping the samples in the desiccators without normal load was not considered problematic.

In contrast to the shear tests to find the peak and residual shear strengths of the samples, in fast shear strength tests, samples in the shear test apparatus were not loaded before testing, until its vertical displacement became stable.

Microsoft Excel was used to record the ADU readings in order to perform the calculations, and to create graphs and charts. From those graphs, the maximum and residual shear stresses, the corresponding deformations and the internal friction angles were calculated. Furthermore, the strength changes during the tests were observed.

Strength gaining (thixotropy) of the pre-sheared clays with time is believed to result mainly from a change in yield stress [29]. This can be explained if it is accepted that shear breaks interparticle bonds causing a disruption of the stable fabric. In this interpretation, the strength recovery on ageing implies that conditions in the system favor re-establishment of bonds broken during shear and a fabric similar to that in the undisturbed material reconstructed. The alternative proposition is that the changes in yield stress which 
accompany shear or lack of disturbance following shear result from reversible changes in the thickness of the layers of oriented water molecules associated with the clay minerals.

After strength gaining, fast shear tests give higher strength values than the residual strength because of the speed of the shearing. Depending on the shearing speed the fabric of the clay, shearing surface resists more or less against the movement. With increasing the speed the resistance increases.

Texture, plasticity or water absorption capacities of the clay make the resistance level change. More plastic clays show less resistance to the fast shearing due to greater number of weak water bonding. Clay particles make ionic bonds with water and water separates the clay particles and provides water pillows between particles. Therefore, friction and bonding between particles are prevented and more plastic clay show less resistance against shearing.

\section{Test Results and Discussion}

Artificially prepared clay specimens were consolidated in EL25-0402 model oedometers. Those specimens were, then, sheared in a $100 \mathrm{~mm}$ by $100 \mathrm{~mm}$ direct shear box in subsequent sets of loadings related with the desired normal stress values until they reached their residual shear strength values. After resting periods that were at least 21 days, specimens were fast sheared to simulate the effects of an earthquake on previously failed over-consolidated clayey soil slopes.

\subsection{Direct shear test result}

Each of consolidated specimens was put into the direct shear test ring and the box was filled with distilled water. Here $400 \mathrm{kPa}$ pre-consolidation pressure was applied and consolidation response was monitored by
ADU. ADU gave the consolidation graphics and then $\mathrm{t} 50$ values for both kinds of samples determined. Then, corresponding normal pressure $(50 \mathrm{kPa}, 75 \mathrm{kPa}$ or 100 $\mathrm{kPa}$ ) was applied. The shear test strain rates were calculated with the formulas below.

$$
\mathrm{t}_{\mathrm{f}}=50 \times \mathrm{t}_{50}
$$

Then, from

$$
\varepsilon(\mathrm{mm} / \mathrm{min})=\Delta / \mathrm{t}_{\mathrm{f}}
$$

Where

$t_{50}=$ the time required to complete $50 \%$ consolidation

$\mathrm{t}_{\mathrm{f}} \quad=$ failure time

$\varepsilon \quad=$ strain rate

$\mathrm{t}_{50}$ for Kaolinite is $\approx 2$ minutes and for the mixture it is $\approx 3$ minutes. Therefore, $t_{f}$ values are 100 minutes and 150 minutes respectively. Then $\varepsilon$ values become 0.1 $\mathrm{mm} / \mathrm{min}$ and $0.0667 \mathrm{~mm} / \mathrm{min}$ respectively.

After determination of the shear strains, the samples sheared under the corresponding normal loads. The shear tests were repeated at least three times in forward and backward directions. The peak and residual values and related graphics are shown below.

In the Table 2 and 3 , the peak and residual values can be seen. The average values of the shear strengths of the samples were used to determine the internal friction angle and cohesion intercept.

Figures 17 - 19 show the peak, residual and fast shear graphics of Kaolinite + Bentonite mixture samples under three different normal stresses and Figures 20 22 illustrate the peak, residual and fast shear strength of the Kaolinite samples under again three different normal loadings.

\begin{tabular}{|c|c|c|c|c|c|c|c|c|}
\hline $\begin{array}{l}\text { Type of } \\
\text { Spec. }\end{array}$ & No. & $\begin{array}{c}\sigma \\
(\mathrm{kpa})\end{array}$ & $\begin{array}{c}\text { Peak } \tau \\
(\mathrm{kPa})\end{array}$ & $\begin{array}{c}\text { Avg. Peak } \tau \\
(\mathrm{kPa})\end{array}$ & Res. $\tau(\mathrm{kPa})$ & $\begin{array}{l}\text { Avg. Res. } \tau \\
(\mathrm{kPa})\end{array}$ & $\begin{array}{l}\text { Fast } \tau \\
(\mathrm{kPa})\end{array}$ & $\begin{array}{l}\text { Avg. Fast } \tau \\
(\mathrm{kPa})\end{array}$ \\
\hline \multirow{15}{*}{$\mathrm{K}+\mathrm{B}$} & 1 & \multirow{5}{*}{100} & 57.0 & \multirow{5}{*}{60.5} & 44.0 & \multirow{5}{*}{48.0} & 47.0 & \multirow{5}{*}{50.0} \\
\hline & 2 & & 62.0 & & 48.0 & & 50.0 & \\
\hline & 3 & & 64.0 & & 51.0 & & 48.0 & \\
\hline & 4 & & 61.0 & & 52.0 & & 53.0 & \\
\hline & 5 & & 58.5 & & 45.0 & & 52.0 & \\
\hline & 6 & \multirow{5}{*}{75} & 51.0 & \multirow{5}{*}{53.0} & 43.0 & \multirow{5}{*}{46.0} & 48.0 & \multirow{5}{*}{52.0} \\
\hline & 7 & & 53.0 & & 45.5 & & 51.0 & \\
\hline & 8 & & 55.0 & & 49.0 & & 56.0 & \\
\hline & 9 & & 52.0 & & 47.0 & & 52.0 & \\
\hline & 10 & & 54.0 & & 45.5 & & 53.0 & \\
\hline & 11 & \multirow{5}{*}{50} & 40.0 & \multirow{5}{*}{40.0} & 30.0 & \multirow{5}{*}{30.5} & 36.0 & \multirow{5}{*}{37.0} \\
\hline & 12 & & 41.0 & & 30.5 & & 36.5 & \\
\hline & 13 & & 40.5 & & 31.0 & & 37.0 & \\
\hline & 14 & & 40.0 & & 31.0 & & 38.0 & \\
\hline & 15 & & 38.5 & & 30.0 & & 37.5 & \\
\hline
\end{tabular}

Table 2. Shear test results 
Table 3. Shear test results

\begin{tabular}{|c|c|c|c|c|c|c|c|c|}
\hline $\begin{array}{l}\text { Type of } \\
\text { Spec. }\end{array}$ & No. & $\begin{array}{c}\sigma \\
(\mathrm{kpa})\end{array}$ & $\begin{array}{c}\text { Peak } \tau \\
(\mathrm{kPa})\end{array}$ & $\begin{array}{l}\text { Avg. Peak } \tau \\
(\mathrm{kPa})\end{array}$ & Res. $\tau(\mathrm{kPa})$ & $\begin{array}{l}\text { Avg. Res. } \tau \\
(\mathrm{kPa})\end{array}$ & $\begin{array}{l}\text { Fast } \tau \\
(\mathrm{kPa})\end{array}$ & $\begin{array}{l}\text { Avg. Fast } \tau \\
(\mathrm{kPa})\end{array}$ \\
\hline \multirow{15}{*}{ K } & 16 & \multirow{5}{*}{100} & 75.0 & \multirow{5}{*}{72.5} & 63.0 & \multirow{5}{*}{65.0} & 73.0 & \multirow{5}{*}{76.5} \\
\hline & 17 & & 74.0 & & 64.0 & & 76.0 & \\
\hline & 18 & & 70.0 & & 67.0 & & 80.0 & \\
\hline & 19 & & 72.5 & & 68.0 & & 76.5 & \\
\hline & 20 & & 71.0 & & 63.0 & & 77.0 & \\
\hline & 21 & \multirow{5}{*}{75} & 56.0 & \multirow{5}{*}{56.0} & 52.0 & \multirow{5}{*}{53.5} & 60.0 & \multirow{5}{*}{58.0} \\
\hline & 22 & & 55.5 & & 52.0 & & 56.5 & \\
\hline & 23 & & 55.5 & & 53.0 & & 57.0 & \\
\hline & 24 & & 56.0 & & 54.0 & & 56.0 & \\
\hline & 25 & & 57.0 & & 55.5 & & 60.5 & \\
\hline & 26 & \multirow{5}{*}{50} & 46.0 & \multirow{5}{*}{47.5} & 40.0 & \multirow{5}{*}{41.0} & 57.0 & \multirow{5}{*}{53.5} \\
\hline & 27 & & 47.0 & & 40.5 & & 55.0 & \\
\hline & 28 & & 49.0 & & 42.0 & & 50.0 & \\
\hline & 29 & & 48.0 & & 41.0 & & 53.0 & \\
\hline & 30 & & 47.5 & & 41.5 & & 52.5 & \\
\hline
\end{tabular}

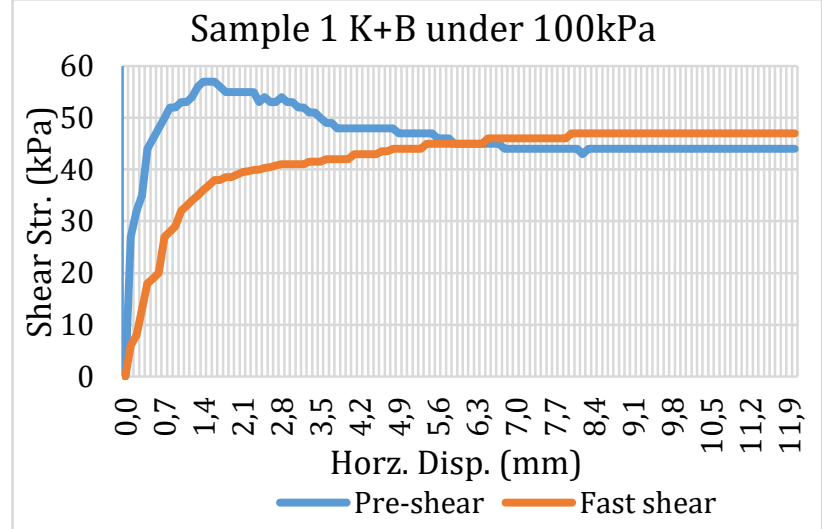

Figure 17. Shear test graph for Sample 1 under $100 \mathrm{kPa}$.

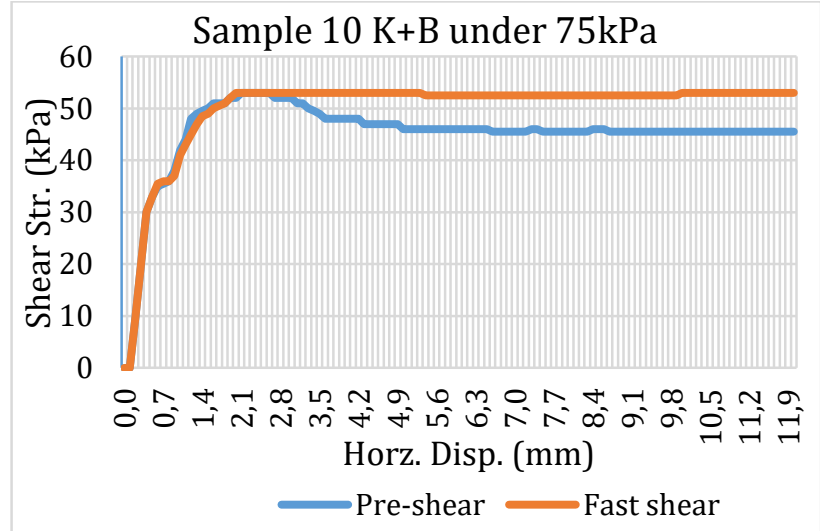

Figure 18. Shear test graph for Sample 10 under $75 \mathrm{kPa}$.

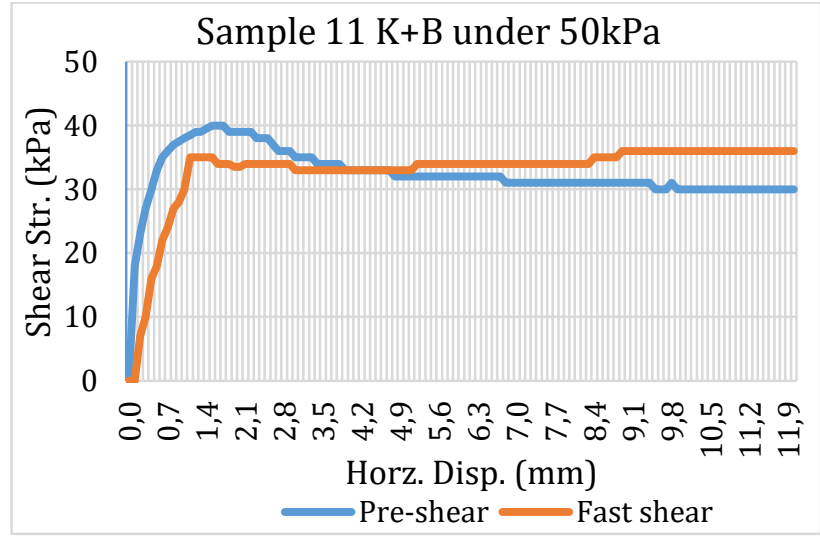

Figure 19. Shear test graph for Sample 11 under $50 \mathrm{kPa}$.

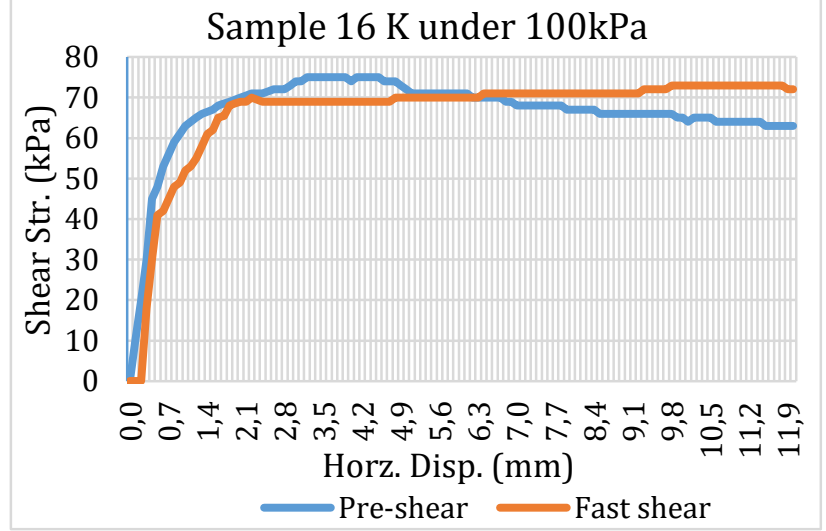

Figure 20. Shear test graph for Sample 16 under $100 \mathrm{kPa}$.

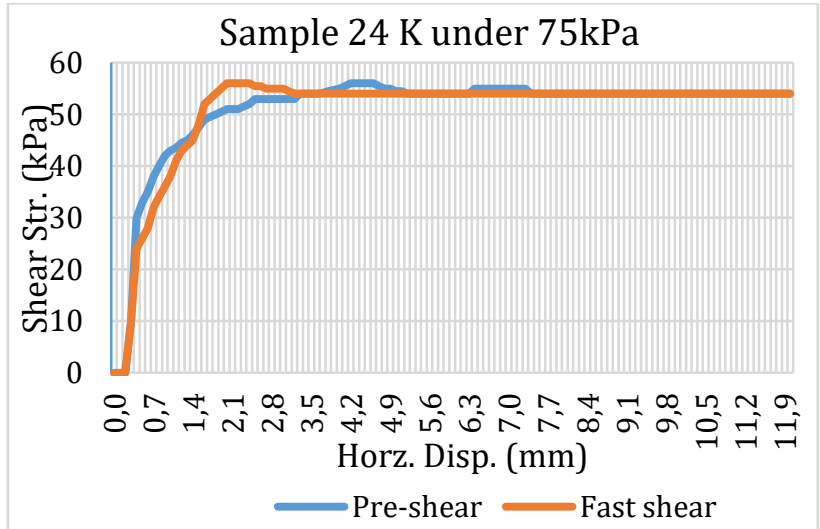

Figure 21. Shear test graph for Sample 24 under $75 \mathrm{kPa}$.

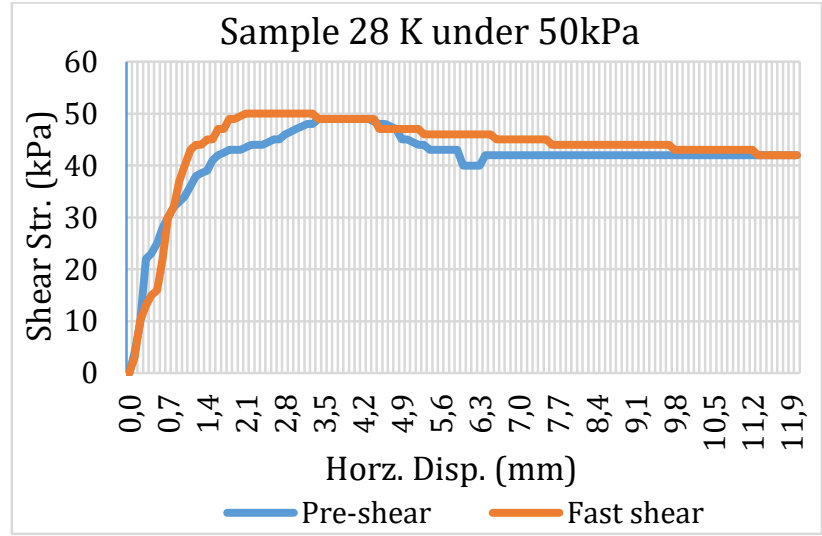

Figure 22. Shear test graph for Sample 28 under $50 \mathrm{kPa}$. 


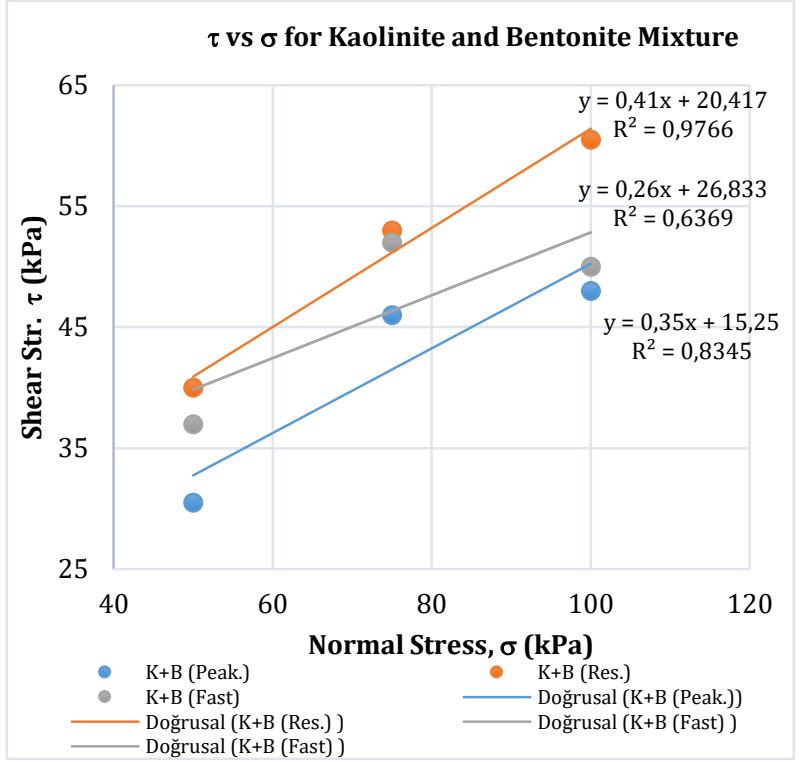

Figure 23. $\tau$ versus $\sigma$ graphics for Kaolinite and Bentonite mixture.

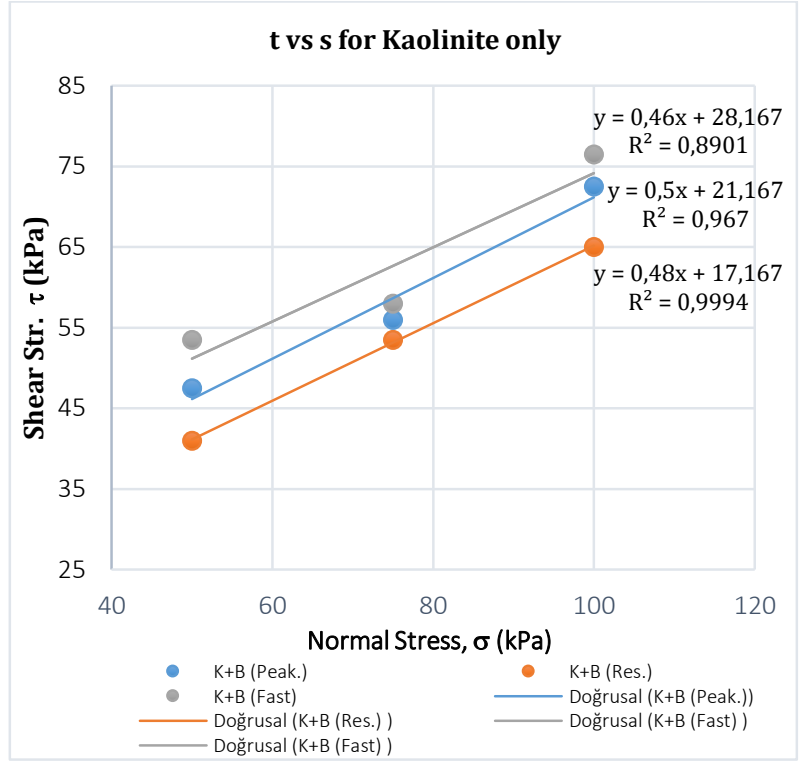

Figure 24. $\tau$ versus $\sigma$ graphics for Kaolinite only samples.

Table 4 gives the peak, residual and fast shear cohesion and internal friction angle values according to $\tau$ vs $\sigma$ graphics. For the mixture and for Kaolinite only sample, $\tau$ vs $\sigma$ graphics can be seen in Figure 23 and Figure 24 respectively.

Table 4. Peak, residual and fast shear cohesion and internal friction angle values

\begin{tabular}{ccccccc}
\hline $\begin{array}{c}\text { Sample } \\
\text { Type }\end{array}$ & \multicolumn{2}{c}{ Peak } & \multicolumn{2}{c}{ Residual } & \multicolumn{2}{c}{ Fast } \\
& $\begin{array}{c}\mathrm{c} \\
(\mathrm{kPa})\end{array}$ & $\begin{array}{c}\phi \\
\mathrm{o})\end{array}$ & $\begin{array}{c}\mathrm{C}_{\mathrm{r}} \\
(\mathrm{kPa})\end{array}$ & $\begin{array}{c}\phi_{\mathrm{r}} \\
(\mathrm{o})\end{array}$ & $\begin{array}{c}\mathrm{C}_{\mathrm{f}} \\
(\mathrm{kPa})\end{array}$ & $\begin{array}{c}\phi_{\mathrm{f}} \\
(\mathrm{o})\end{array}$ \\
\hline $\mathrm{K}+\mathrm{B}$ & 20.4 & 22.3 & 15.2 & 19.3 & 26.8 & 14.6 \\
$\mathrm{~K}$ & 21.2 & 26.6 & 17.2 & 25.6 & 28.2 & 24.7 \\
\hline
\end{tabular}

Table 5. Peak, residual and fast shear cohesion and internal friction angle values for parallel lines model

\begin{tabular}{ccccc}
\hline $\begin{array}{c}\text { Sample } \\
\text { Type }\end{array}$ & $\phi(\mathrm{o})$ & Peak & $\begin{array}{c}\text { c }(\mathrm{kPa}) \\
\text { Residual }\end{array}$ & Fast \\
\hline $\mathrm{K}+\mathrm{B}$ & 18.18 & 26.34 & 17.33 & 20.79 \\
$\mathrm{~K}$ & 28.01 & 18.42 & 12.34 & 21.74 \\
\hline
\end{tabular}

In Table 5, the results of a different approach from the same graphs seen as in Figure 25 and Figure 26. Here general tendency is determined by a line and the other two lines have the same slopes. Here the slope is same for all lines but the cohesions are different.

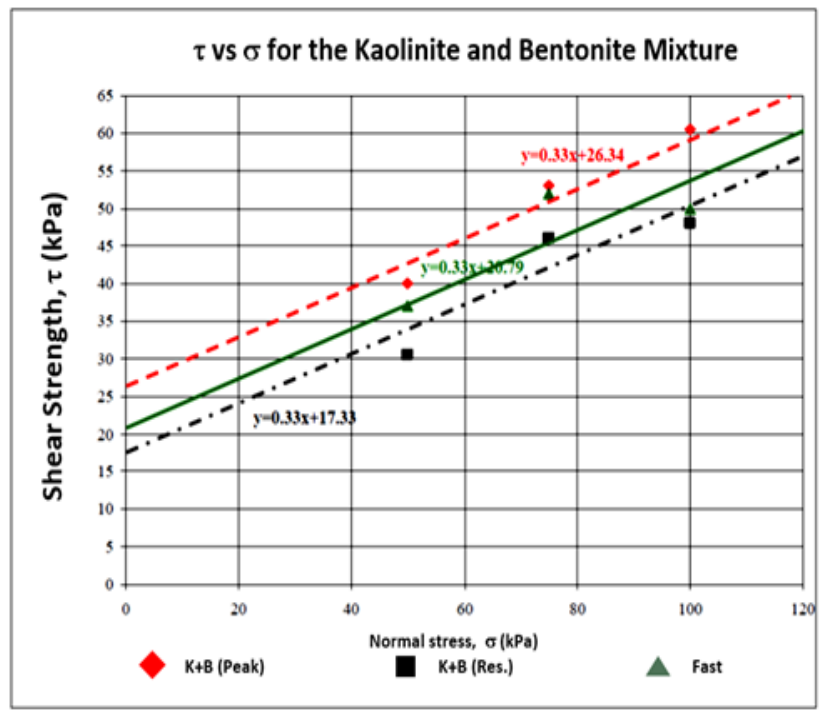

Figure 25. Parallel line representation of $\tau$ versus $\sigma$ graphics for Kaolinite and Bentonite mixture.

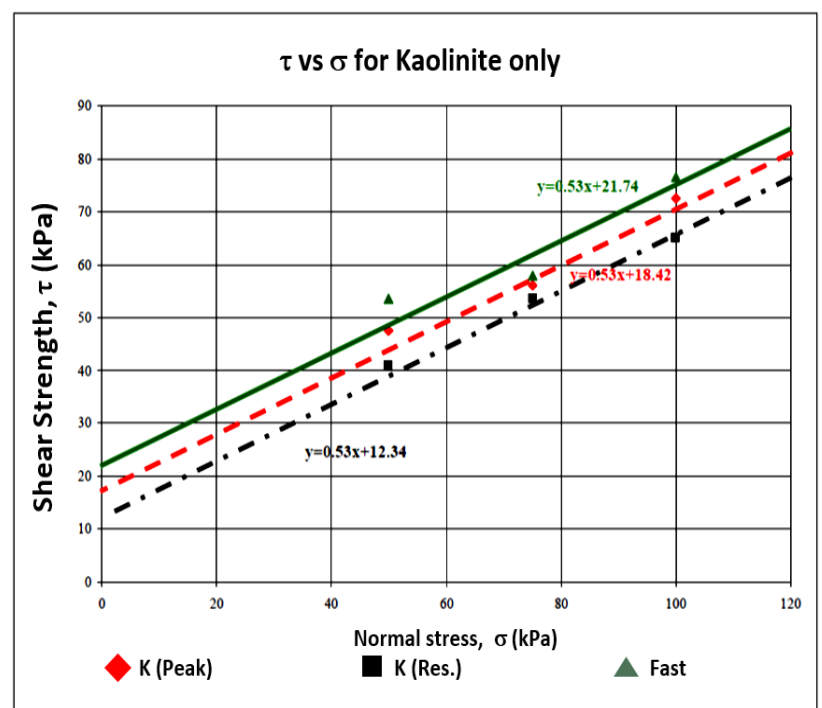

Figure 26. Parallel line representation of $\tau$ versus $\sigma$ graphics for Kaolinite only samples.

The strength changes from the first shear test to residual strengths and from residual to fast shear strength are shown in the Table 6.

Table 6. Shear strength changes

\begin{tabular}{|c|c|c|c|c|c|}
\hline Type & $\begin{array}{l}\text { Normal } \\
\text { Stress } \\
(\mathrm{kPa})\end{array}$ & $\begin{array}{l}\text { Avg. } \\
\text { Peak } \\
\text { Shr. } \\
\text { Str. } \\
(\mathrm{kPa})\end{array}$ & $\begin{array}{l}\text { Avg. } \\
\text { Res. } \\
\text { Shr. } \\
\text { Str. } \\
(\mathrm{kPa})\end{array}$ & $\begin{array}{l}\text { Avg. } \\
\text { Fast } \\
\text { Shr. } \\
\text { Str. } \\
(\mathrm{kPa})\end{array}$ & $\begin{array}{l}\% \\
\text { change } \\
\text { btw. Res. } \\
\& \quad \text { Fast } \\
\text { Shr. Str. }\end{array}$ \\
\hline \multirow{3}{*}{$\mathrm{K}+\mathrm{B}$} & 100 & 60.5 & 48.0 & 50.0 & 4.17 \\
\hline & 75 & 53.0 & 46.0 & 52.0 & 13.04 \\
\hline & 50 & 40.0 & 30.5 & 37.0 & 21.31 \\
\hline \multirow{3}{*}{ K } & 100 & 72.5 & 65.0 & 76.5 & 17.69 \\
\hline & 75 & 56.0 & 53.5 & 58.0 & 8.41 \\
\hline & 50 & 47.5 & 41.0 & 53.5 & 30.49 \\
\hline
\end{tabular}




\section{Concluding Remarks}

The main purpose of this research was to determine the effects of fast loadings like earthquakes on previously failed over-consolidated low and high plastic clayey soil slopes. For this purpose, artificially over-consolidated clayey specimens were prepared and tested in a direct shear test apparatus to observe the strain softening behavior until their residual strengths were reached. After the specimens reached their residual strengths, they rested at least 21 days in desiccators, then re-tested with fastest speed the shear apparatus can provide to determine their fast impact (dynamic) strengths.

To achieve these objects, a comprehensive series of direct shear tests were carried out on artificially prepared specimens. For these experiments, clayey samples with two different plasticities were prepared in the laboratory from slurry. These samples were used to simulate the strain softening behavior of overconsolidated clayey soils as well as to simulate the effects of fast loading, i.e. earthquakes.

The results of the tests showed that the peak shear strength parameters were reduced to residual strength values when excessive deformation was applied. The cohesion of the high plastic clay samples reduced from $c^{\prime}=20.4 \mathrm{kPa}$ to $c^{\prime}{ }_{\mathrm{r}}=15.2 \mathrm{kPa}$, the low plastic ones have $c^{\prime}=21.2 \mathrm{kPa}$ and $c^{\prime}{ }_{\mathrm{r}}=17.2 \mathrm{kPa}$ and the internal friction angle of the high plastic clay samples reduced from $\varphi^{\prime}=$ $22.3^{\circ}$ to $\varphi_{\mathrm{r}}^{\prime}=19.3^{\circ}$ and the low plastic ones have $\varphi^{\prime}=$ $26.6^{\circ}$ and $\varphi_{r}^{\prime}=25.6^{\circ}$.

The samples that failed and reached their residual strength were subjected to approximately same resting periods to gain strength. The effects of fast shear load that was parallel to the shear plane observed. To evaluate the effect of normal stress on the fast shear strength of over-consolidated pre-failed clayey soil slopes, specimens were tested under different normal stresses after shearing and waiting for some period. During the resting period, specimens showed increase in their fast shear strengths with increasing vertical stress.

The cohesion and internal friction angle values obtained from the fast shear tests showed that whereas the cohesion increased significantly, the internal friction angle decreased slightly for Kaolinite samples but decreased significantly for Kaolinite + Bentonite mixture. For Kaolinite + Bentonite mixture $c^{\prime}{ }_{r}=15.2$ $\mathrm{kPa}$ and $\mathrm{C}_{\mathrm{F}}(\mathrm{K}+\mathrm{B})=26.8 \mathrm{kPa}$, for Kaolinite only samples $\mathrm{c}^{\prime}{ }_{\mathrm{r}}(\mathrm{K})=17.2 \mathrm{kPa}$ and $\mathrm{c}_{\mathrm{F}}(\mathrm{K})=28.2 \mathrm{kPa}$, and the internal friction angles reduced as; from $\quad \varphi^{\prime}{ }_{\mathrm{r}}(\mathrm{K}+\mathrm{B})=19.3^{\circ}$ to $\varphi_{\mathrm{F}}(\mathrm{K}+\mathrm{B})=14.6^{\circ}$ and from $\varphi^{\prime}{ }_{\mathrm{r}}(\mathrm{K})=25.6^{\circ}$ to $\varphi_{\mathrm{F}}(\mathrm{K})=$ $24.7^{\circ}$. Here, also it can be seen that the cohesion values for fast shearing are higher than the first shearing tests for both $\mathrm{K}+\mathrm{B}$ and Kaolinite samples, $\mathrm{C}_{\text {Fast }}>\mathrm{C}_{\text {Peak }}>$ CResidual.
The other approach about the same graphs of results is parallel lines. Here general tendency is represented by a line and the other two lines with the same slope represent the other data. From this approach it can be seen that Kaolinite only samples show significant increase in cohesion values. General tendency, when slope is kept constant, is CPeak $>$ CResidual $<$ CFast.

According to the results of the parallel lines approach, again samples have another interesting response to fast shearing. The cohesion value for fast shearing is higher than the first shearing for only Kaolinite samples but this time $\mathrm{K}+\mathrm{B}$ samples have lower cohesion value than the first time shearing cohesion.

Even after a short period, like 21 days, fast shear test results indicated that shear strength parameters for Kaolinite + Bentonite mixed samples were very close to the peak strengths, but Kaolinite samples have higher values than former states. Therefore, based on the experimental results obtained for the Kaolinite clay and Kaolinite + Bentonite mixture, it can be argued that using residual values for a pre-failed over-consolidated slope while analyzing fast loading like earthquake conditions, is very conservative and low plastic clays has higher strength gaining capacity then the high plastic clays in the same period.

Another interesting result is recognized from the strength changes and normal stress relations as seen in Table 6. Especially in $\mathrm{K}+\mathrm{B}$ mixture, results of percent changes show that with increasing OCR, strength gaining gets higher values. This means that the OCR value is important when the shear strength values taken into account.

\section{References}

[1] Wentworth, C. K., 1922. A Scale of Grade and Class Terms for Clastic Sediments. J. Geol., Vol. 30, pp. 377-392.

[2] Taylor, D. W., 1948. Fundamentals of Soil Mechanics. John Wiley and Sons Inc., London, pp. 362-381.

[3] Bromhead, E. N., 1992. The Stability of Slopes. Blackie Academic \& Professional, Glassgow, Chapman \& Hall, New York, pp. 414.

[4] Skempton, A.W., 1964. Long-term Stability of Clay Slopes. Geotechnique, Vol. 14, pp. 75-102.

[5] Gregory, C.H. and Delabeche, H., 1844. On railway cuttings and embankments; with an account of some slips in the London clay, on the line of the London and Croydon Railway. Min. Proc. Inst. C.E.,Vol. 3, pp. 135-145.

[6] Skempton, A.W., and Golder, H. Q., 1948. Practical Examples of the $\phi=0$ Analysis of the Stability of Clays. Proceedings of the Second International Conference of Soil Mechanics, Rotterdam, Vol. 2, pp. 63-70. 
[7] Terzaghi, K., 1936. Stability of Slopes in Natural Clay. Proceedings of the First International Conference of Soil Mechanics, Harvard, Vol. 1, pp. 161-165.

[8] Terzaghi, K., and Peck, Ralph B., 1948. Soil Mechanics in Engineering Practice. John Wiley and Sons, New York, pp. 566.

[9] Hutchinson, J. N. and Bhardari, R. K., 1971. Undrained Loading; a Fundamental Mechanism of Mudflows and other Mass Movements. Geotechnique, Vol. 21, pp. 353-358.

[10] Stark, T. D., and Eid, H. T., 1997. Slope Stability Analyses in Stiff Fissured Clays. Journal of Geotechnical and Geoenvironmental Engineering, Vol. 123, No. 4, pp.335-343.

[11] Chandler, R. J. and Skempton, A. W., 1974. The Design of Permanent Cutting Slopes in Fissured Clays. Geotechnique, Vol. 24, No. 4, pp. 457-466.

[12] Imperial College, University of London. A. W. Skempton. Slope Stability of Cuttings in Brown LondonClay. https://www.issmge.org/uploads/publications/ 1/36/1977_03_0003.pdf. (Access Date: 14.04.2020)

[13] Kuwano, J., Ishihara, K., Kuwano, R., and Yoshimine, M., 1991. Dynamic Strength of Cohesive Soils from Landslide Sites. Proceedings of the First Young Asian Geotechnical Engineers Conference, pp. 207-216.

[14] Lupini, J. F., Skinner, A. E., and Vaughan, P. R., 1981. The Drained Residual Strength of Cohesive Soils. Geotechnique, Vol. 31, No. 2, pp. 181 - 213.

[15] Martins, J. P., 1983. Shaft resistance of axially loaded piles in clay. Ph.D. Thesis, University of London, pp. 63.

[16] Lemos, L. J., 1986. The Effects of Rate on the Residual Strength of Soil. Ph.D. Thesis, University of London, pp. 83.

[17] Tika, T. E., 1989. The Effect of Rate of Shear on the Residual Strength of Soil. Ph. D. Thesis, University of London, pp. 494.

[18] Lemos, L. J. L., Skempton, A. W., and Vaughan, P. R., 1985. Earthquake loading of shear surfaces in slopes. Proc. XI. Int. Conf Soil Mech. \& Foundn. Engng., San Francisco.Vol. 4, pp. 1955-1958.

[19] Tika, T. E., Vaughan, P. R., and Lemos, L. J., 1996. Fast Shearing of Pre-existing Zones in Soils. Geotechnique, Vol. 46, No. 2, pp. $197-233$.

[20] Skempton, A.W., 1970. First time slides in overconsolidated clays. Geotechnique,Vol. 20, No. 3 , pp. 320-324.

[21] Morgenstern, N. R., Blight, G. R., Janbu, N., and Resendiz, D., 1977. Slopes and Excavations. Proceedings of the Ninth International Conference of Soil Mechanics and Foundation Engineering, Vol. 12, pp. 547-604.

[22] Hvorslev, M. J., 1937. Über die Festigkeitseigenschaften gestörter bindiger Böden. Ingenior Skriftor A., No. 45 Copenhagen, pp. 159.

[23] Tiedemann, B., 1937. Über die Schubfestigkeit bindiger Böden. Bautechnik, Vol. 15., pp. 400-403, 433-435.

[24] Skempton, A. W. and Petley, D. J., 1967. The strength along structural discontinuities in stiff clays. Proc. Geotechnical Conference, Oslo, Vol. 2, pp. 29-46.

[25] Ramiah, B. K. and Purushothama Raj. P., 1971. Influence of strain rate on the residual strength of a kaolinitic clay. Proc. Geotechnical Engineering, J.S.E.A.S.S.E., Vol. 2, pp. 151-158.

[26] Skempton, A.W., 1985. Residual strength of clays in landslides, folded strata and the laboratory. Geotechnique, Vol. 35, No.1, pp. 3-18.

[27] Yatabe, R., N. Yagi, and Enoki, M., 1991. Ring shear characteristics of clays in fracturedzonelandslide. Journal of Geotechnical Engineering, Japan Society of Civil Engineers, No.436/III-16, pp. 93-101.

[28] Suzuki, M., Umezaki, T., Kawakami, H., and Yamamoto, T., 2000. Residual strength of soil by direct shear test. Journal of Geotechnical Engineering, Japan Society of Civil Engineers, No.645/III-50, pp.37-50.

[29] Van Olphen, H., 1963. An Introduction to Clay Colloid Chemistry. Interscience Publication, New York, pp. 301. 